\title{
AN ACADEMIC \\ DRAFT REGULATIONS ON REGIONAL PROCEDURE FOR NOMINATION, SELECTION, APPOINTMENT, INDUCTION AND DISMISSAL OF THE HEAD OF THE VILLAGE
}




\section{FOREWORD}

Our praise and gratitude to Allah SWT on His mercy and grace and His taufiq and guidance, so that the academic paper on Local Regulation Procedure Nominations, Selection, Appointment and Dismissal Inauguration village chief can we accomplish.

The idea to compose academic text emerged from the Department of Community and Village Government (BPMPD) District ...... to formulate society in order to realize an atmosphere conducive to the achievement of prosperity and tranquility of life in a society.

With tersusunya academic paper, is expected to serve as a reference for decision makers District Government

in an effort to encourage and conduct training on the individual, and community groups.

We are fully aware, though have worked out the best in academic papers, but of course there are still weaknesses and shortcomings there may even be an error in the preparation of this paper. Therefore, correction and feedback are we expected, for improving this academic paper.

Finally, on this occasion, we express our gratitude to all parties who have participated assist in contributing thought, attention and assistance to the settlement as well as academic papers to the Regional Regulation Procedure Nominations, Selection, Appointment, Inauguration and Dismissal of the village chief, hopefully helpful.

, February 2018

DRAFTING TEAM 


\section{CHAPTER I INTRODUCTION}

\section{A. Background}

Village governance undergone fundamental changes through the revision of Law No. 32 of 2004 which was replaced by Act No. 6 of 2014 on the village. The amendment is based on historical arguments, philosophical, juridical, and sociological psikopolitik. These arguments are oriented in the effort to organize the village. One of the important issues in structuring the village is the village head filling positions that can not be separated from the institutional design of the village administration.

One substance that Act No. 6 of 2014 regarding structuring institutional arrangements regarding the village is the village, the Village Government institutions composed of village government, Village Consultative Body and the Village Community Institutions. The village government is the village chief who serves as head of the village administration who led the organization of the village administration. The village head has an important role in his capacity as representative of the country close to the community and as a community leader. With such a position, the principle of the regulation of the village chief is:

a) Mentions village head adapted to local designation;

b) The village head serves as the head of the village government and community leadership;

c) The village chief elected democratically and directly by the local community;

d) The candidacy of the head of the village in a direct election does not use political party base so that the head of the village are barred from political party leaders. 
According to Law No. 6 of 2014 concerning the Village and Government Regulation No. 43 of 2014 on the village stated that:

The village is the village or called by other names, hereinafter called the village, is the unity of the legal community who have boundaries that are authorized to regulate and manage the affairs of the government, the interests of the local community by community initiatives, the right of origin, and / or traditional rights recognized and respected within the government system of the Republic of Indonesia.

Formulation of the Plan Local Regulations related to Village Head Election is already very appropriate to be done in line with the enactment of Law No. 6 of 2014 on the village. Some substances changes contained in the new regulations must be implemented by every country especially in the District ....... change social conditions in society that every time can turn requires the authorities in drafting regulations, namely the executive and the legislature should really keen in the formulation so that what is produced will be able to overcome all the problems that exist, including in terms of the implementation of village elections. Moreover, by looking at the condition of the village at this time,

In the draft regulation on procedures for the nomination, election, appointment, appointment and dismissal of the head of the village, there are some new concept is a refinement of the principles and rules that apply during this time. What is meant by the improvement here is a change to the provisions of regulation on procedures for the nomination, election, appointment, appointment and dismissal of the head of the village contained in the existing legislation, namely the District Regulation ......

Number 31 Year 2007 on Procedures for Nominations, Selection, Appointment, Inauguration, Termination Head of Village and the Village, as well as the addition of any new provisions that have not been regulated by regional regulations. 
In order to answer the above issues, one of the grand strategy that is very necessary and urgent is the need to immediately prepare a draft regional regulation on procedures for the nomination, election, appointment, appointment and dismissal of the head of the village to replace the Regional Regulation previous Regional Regulation No. 31 Year 2007 on Nominations, Election, Inauguration and dismissal of Head of Village and the Village for some policies regarding Election village chief and the village already had to adjust to Law No. 6 of 2014 About the village.

\section{B. Identification of problems}

Changes in the legal order of the village as well as the arrangement of the village, followed by the social changes that occurred in the community in the District of ...... a state of society experienced various political shift in the order of social life, the consequences of which must be faced, namely a change in mindset, follow so that the condition of the people becoming increasingly prone to conflict, then that needs to be identified in this study is how the efforts to realize the Local Government District ........ that prosperous through the legal regulation of the procedure for the nomination, election, appointment, appointment and dismissal of the chief.

- What criteria for nomination, election, appointment, appointment and dismissal of the village chief who is restricted and to whom such restrictions apply / applied?

- The problems that faced in the life of the nation, the state and society, so that the need for regulating the nomination, election, appointment, appointment and dismissal of the Head of the village?

- What philosophical arguments, sociological and juridical about the need for setting the nomination, election, appointment, appointment and dismissal of the Head of the village?

- What are the social, economic, and culture that must be 
considered if the provisions on the nomination, election, appointment, appointment and dismissal of the Head of the village?

- What are the goals, direction and range and scope of setting the nomination, election, appointment, appointment and dismissal of the Head of the village?

- How sanction against any person who violates the provisions of the nomination, election, appointment, appointment and dismissal of the Head of the village?

\section{Goals and usage}

\section{Objectives of Academic Paper include:}

1. Formulating criteria for nomination, election, appointment, appointment and dismissal of the village chief who should be restricted and to whom these restrictions apply.

2 Describe the problems encountered in the life of a nation, a state, the settlement requires the existence of arrangements regarding the nomination, election, appointment, appointment and dismissal of the chief.

3. Outlining the philosophical arguments, sociological and juridical about the need for setting the nomination, election, appointment, appointment and dismissal of the chief.

4. Elaborating the social, economic, and culture that must be considered if the provisions on the nomination, election, appointment, appointment and dismissal of the chief.

5. Elaborating on the target, the direction and the range and scope of setting the nomination, election, appointment, appointment and dismissal of the chief.

6. Outlining sanctions against any person who violates the provisions of the nomination, election, appointment, appointment and dismissal of the chief.

7. Determining agencies that have the authority to supervise the nomination, election, appointment, appointment and dismissal 
of the chief.

8.

\section{Academic Manuscript preparation usability}

This academic papers useful as a reference in policy making communities about the nomination, election, appointment, appointment and dismissal of the Head of the village in the district of ...... as a supporting material as well as the requirements of the harmonization process in the filing of the Annual Priority Local Legislation Program ( Prolegda).

\section{Research methods}

The method used in the preparation of this academic paper is a method normative or legal research literature. Correspondingly, the source of legal research in the form of legal materials (primary, secondary and tertiary), such as the Basic Regulation, Legislation, writings, literature and the results of the research will be used.

The primary legal materials consist of legislation, official records or minutes in the making of legislation and decisions of the judges. While secondary materials in the form of all publications on the law which is not an official documents. Publication of the law include text books, dictionaries law, legal journals, and comment comment on the court decision (ingredients tertiary) 1.

Under this method, the data and information obtained will be arranged in a descriptive and systematic to make it easier for policy-making and help in the formulation of norms by the designer Legislation (legal drafter). Academic Manuscript preparation of the nomination, election, appointment, appointment and dismissal of the Head of the village is also supported by comparative studies by taking a secondary law not only from the District, but also from other regions.

In enrich the substance, then the academic paper on procedures for the nomination, election, appointment, appointment and dismissal of the Head of the Village will use 


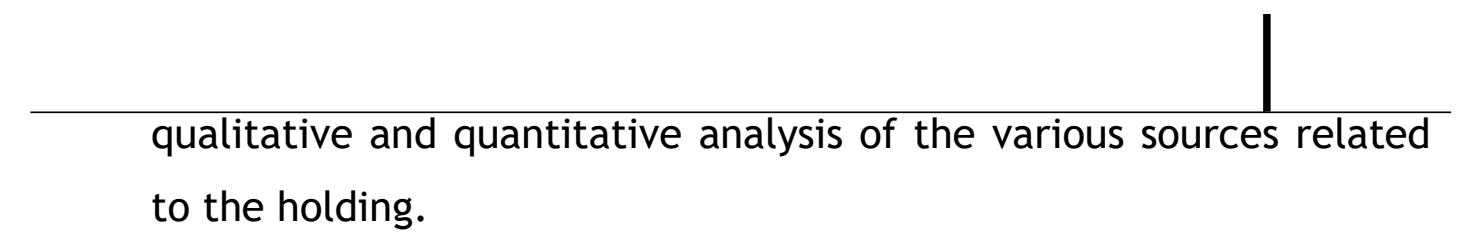

${ }^{1}$ Peter Mahmud Marzuki, Legal Research, Kencana Publishers, 2007, p. 141 


\section{CHAPTER II \\ Theoretical studies EMPIRICAL AND PRACTICE}

\section{A. Theoretical study}

As well as political life in the village which directly touch the most fundamental political interests of the public, local politics is believed to be affecting the lives of every day than national politics. It's as confirmed by Terry Christensen2 that:

"National politics may be associated with the bigger problems that look more attractive Because many media review them. But national politics do not directly Affect the basic issues. While local politics Might look just ordinary insignificant event, but as an individual or as a small group of people, we can influence and Involved in local politics more than the larger national politics that even located far away from us. Local politics occur within a city, region and country. So it is easy to compare what you observe your in one community than a set of other community ".

More Terry Christensen $(1995,1)$ confirms that by definition, local political emphasis on decision making, voting and public policy carried out at the local level when an individual or a small group of people can get involved and influence directly. In addition to the use of local political theory, the study uses the theory of decentralization and regional autonomy to support the use of local political theory. This is due to discuss regional autonomy can not be separated from the discussion of decentralization.

\footnotetext{
${ }^{2}$ Christensen, Terry. 1995. Local Politics: Governing at the Grassroots. California: Wadsworth Publishing Company.
} 
According Sarundajang3 political point of decentralization as a power play meant to prevent the accumulation of power on one side that can ultimately lead to tyranny. Organizers of decentralization considered an act of democratization to attract people to participate in government and train themselves in the use of democratic rights. In the political field, because autonomy is the fruit of a policy of decentralization and democratization, it should be understood as a process to open up space for the birth of the head of local government elected democratically. Autonomy opens the possibility of ongoing governance responsive to the public interest and maintaining a decision-making mechanism obey the principle of public accountability.

While the discussion of village autonomy is often associated with autonomy and even often disamaartikan. Though the term autonomy and village autonomy different from each other. Village autonomy can not be understood as a gift, or the consequences of their autonomy. Village autonomy has been around a long time. In fact, if traced from the historical existence of villages in Indonesia, it is obvious that basically came first village autonomy than the regional autonomy.

Explanation of village autonomy can refer Kartohadikoesoemo4 Soetardjo opinion that autonomy is attached to the village. According to him:

"... the village area is the oldest of the autonomous region. It was established before the birth of a greater coordination area and before the birth of states (kingdoms). Therefore he has the right of full autonomy. his power

\footnotetext{
${ }^{3}$ Sarundayang, SH 1999. Reverse Flow Power to the Regional Center. Jakarta: Sinar Harapan.

${ }^{4}$ Kartohadikoesomo, Soetardjo. 1984. Village. Jakarta: PT Balai Pustaka. P. 182
} 
not only contain government in the narrow sense (bestuur), but also contains the government in a wider sense (regering), because the village is also in charge of: the courts, law (legislative), the police, even the defense also. So the village area has a very broad autonomy, much wider than the autonomy of the regions larger established at a later date ... "

The village as a community unit also has a tradition of selecting leaders. The tradition over time has evolved in line with the development and growth of the village itself. Currently the village leaders to make the selection is done through village elections. Village elections although in a simple form is a political system, which is part of the political systems of other larger and more complex.

According HAW Widjaja5, villages in political views is a democratic society, a society that bases itself on the people's sovereignty. Village democracy that is regarded as a democracy "original" that can be used as an orientation in the development of modern democracy at the national level, with features such as consultation, deliberation village and village elections by the people in the village, from the candidates they propose themselves.

So, the village has been formally recognized as a democratic entity that has the autonomous power to organize independently of government according to the will and needs formulated by the citizens themselves. Among scientists appeared two poles of opinion on this matter. On the one hand say that the village government organization including the selection process

\footnotetext{
${ }^{5}$ Widjaja, HAW, 2008. Autonomy Autonomy is the original village, Round and Whole. PT.RajaGrafindo Persada. Jakarta.
} 
its leadership through the election of village chief is not a form of democracy, while on the other hand said that the village government with leadership selection process is a real form of direct democracy is even mentioned as a true democracy.

View of the first pole among others proposed by Justun MVD Kroef (1965) in his article titled "Far Aid and Social Tradition in Indonesia and Agrarian Reform and Indonesian Communist Party" which says that: "The Indonesian village is not a democracy, nor does it provide a basis for democratic technique of organization and operation as These are understood in the west ". MVD Justun refutation of the opinion Kroef often mentioned by experts from Indonesia. Opinion Justun MVD Kroef gave birth to a second glance that says that the village with its autonomy of governance including the village head election process is a form of democracy. This view is shared by most of the thinkers Indonesia. Even democracy is often said that life in the village is a source of inspiration for the democratic life of the Indonesian nation. One that suggests this view is Ina E. Slamet6 that: "democracy at the village instead of Western democracy, but a genuine democracy of primitive society would not recognize social stratification". While Koentjoro Poerbopranoto (in Wasistiono7) said that democracy in the legal community unit such as villages and similar names as deliberative democracy, democracy, mutual aid or Indonesia8 style democracy.

\footnotetext{
${ }^{6}$ Slamet, Ina E. 1965. Principles of Rural Community Development. Djakarta: Bharata. P. 64

${ }^{7}$ Wasistiono, Sadu. 1993. Head of Village and Dynamics election. Bandung. Publisher Blooming Rahayu. P. 83

${ }^{8}$ Yani neneng Yuningsih. 2016. Democracy In The Village Head Election? Village Case Study By typology Traditional, Transitional and Modern In West Java Province Year of 2008- 2013. The Journal of Politics, Vol. 1, No. 2.
} 
The assertion was further confirmed Mohammad Hatta (in Sulaeman9) that such democracies collectively called democracy which contains within it the social democratic ideals. According to Hatta: "In the villages that the democratic system is still strong and healthy living as part of the customs essentials, essentially a communal land ownership that everyone feels that he must act by mutual consent when conducting economic activities".

The debate over whether the political dynamics in the process of village elections are part of the embodiment of democratic values or not to refer to the five criteria of the democratic ideal of Robert Dahl10 (1989), namely:

1. Effective participation (effective participation); Their common and equal opportunity to participate.

2. Voting equality at the decisive stage (equity options); The guarantee of equal votes of each option was calculated.

3. Enlightened understanding (an adequate understanding); The existence of an adequate understanding to locate and determine the best option.

4. Control of the agenda (control of the agenda); The opportunity to define a political problem.

5. Inclusiveness (inclusive); and the absence of an exception for all citizens / voters.

${ }^{9}$ Sulaiman, Zulfikri. 2010. For Indonesian Democracy: Political Thought Bung Hatta. Jakarta: Book Publishers Compass.

${ }^{10}$ Dahl, Robert. 1989. Democracy and Its Critics. New Haven: Yale University Press 


\section{The concept of the village head elections}

Needs to be understood that the implementation of village elections is an activity that heavy, cumbersome and relatively long circuit and takes no singkat11.

According to the United Nations Development Program (UNDP), Good Governance has eight (8) characteristics are as follows: First, Participation. Every citizen has a voice in decisionmaking, either directly or through a system of representation. Such participation is built on freedom of association and participate constructively. Second, the Rule of Law. The legal framework should be fair and carried out indiscriminately, especially the law on human rights (HAM). Third, Transparency. Transparency is built on the basis of the information flow. Information can be understood and can be monitored. Fourth, Responsiveness. Institutions and processes should try to serve all "stakeholders". Fifth, Consensus Orientation. Good governance mediates differing interests to obtain the best choices for the wider interest. Sixth, Effectiveness and Effeciency. Processes and institutions the best possible result in accordance with what is outlined by using the resources available. Seventh, Accountability. The decision-makers in government, the private and the public sector (civil society) is responsible to the public and stakeholders agencies. Eighth, Strategic Vision. Leaders and the public must have the perspective of good governance and human development are broad and far ahead in line with what is required for such development. Processes and institutions the best possible result in accordance with what is outlined by using the resources available. Seventh, Accountability. The decision-makers in government, the private and the public sector (civil society) is responsible to the public and stakeholders agencies. Eighth, Strategic Vision. Leaders and the public must have the perspective of good governance and human development are broad and far ahead in line with what is required for such development. Processes 
and institutions the best possible result in accordance with what is outlined by using the resources available. Seventh, Accountability. The decision-makers in government, the private and the public sector (civil society) is responsible to the public and stakeholders agencies. Eighth, Strategic Vision. Leaders and the public must have the perspective of good governance and human development are broad and far ahead in line with what is required for such development.

Of the eight characteristics of the above can be seen that in fact inseparable from the idea of the public or the people's seat as one of the components that must be considered engagement, this is a logical consequence of the country with a democratic form of government. According to Amir Machmud, as quoted by Mohammad Mahfud MD, said that the state (with the form of government) democracy is a country that is organized based on the will and the will of the people, or if the terms of organization it (democracy) means the organizing countries carried out by the people themselves or on consent of the people for sovereignty rests with the people.

The village head is elected directly by and from villagers in Indonesian citizens who meet the requirements with a term of 6 (six) years from the date of appointment. The village head can be served at most three (3) consecutive terms in a row or not consecutively.

The requirements for the village head candidate as provided for in Article 33 of Law No. 6 of 2014 as follows:

a. Citizen of the Republic of Indonesia;

b. Fear of God Almighty;

c. Uphold and practice Pancasila, implement the Constitution of the Republic of Indonesia Year 1945, as well as maintain the integrity of the Unitary Republic of Indonesia and Unity;

d. Most low-educated junior high school graduate or equivalent;

e. Aged at least 25 (twenty five) years at the time of registering;

f. Willing to be nominated to be head of the village; 


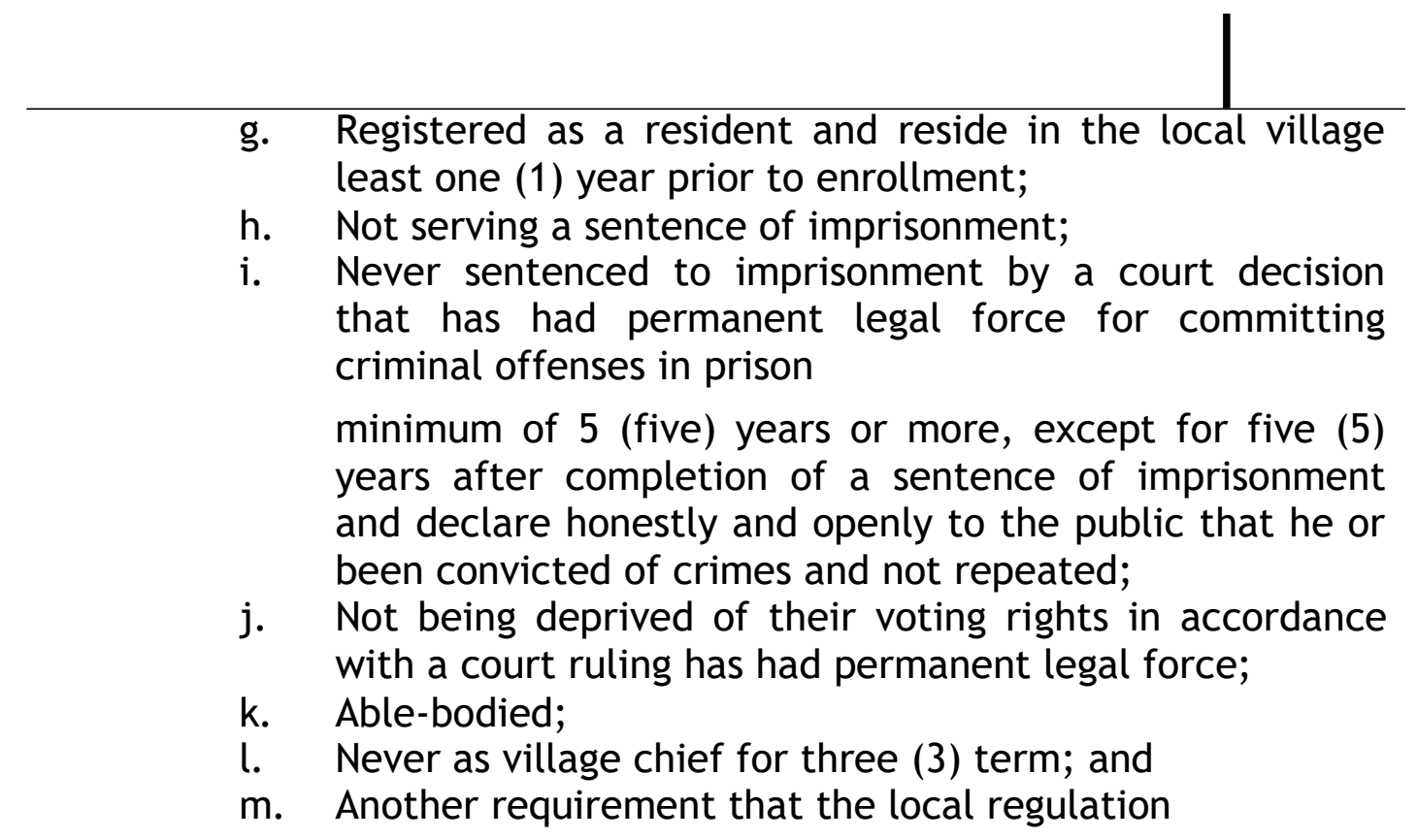

${ }^{11}$ Kasman Siburian, SH, MH. 2012. Analysis System Updates election of village chief in Indonesia 


\section{B. Assessment Principles / Principle}

1. Utility Function

An Act should also pay attention to the principle or principles of benefit. The principle of merit in the establishment of a Law refers to the notion that The law provides or bring benefit to the people. Principle or principles is better known by the term "greatest good for the greatest number of citizens" which was introduced by Jeremy Bentham12.

Restrictions on the activities of the nomination, election, appointment, appointment and dismissal of the Head of the Village by directing the public on the activities that constitute the usefulness of what will be regulated in the area carried out jointly with the aim to achieve harmony in life,

2. Principle of Public Interest

The principle of public interest is a principle which is based on the authority of the state to protect and regulate the wider community. In this case the state can determine

\footnotetext{
${ }^{12}$ Jeremy Bentham, An Introduction to the Principles of Morals and Legislation, Batoche Books: Kitchener, ON Canada, 2000, p. 14.
} 
all the circumstances and events that are compatible with the public interest.

Principle purpose is to realize the common good order and security in the whole society. Regulation relating to the public interest is not related to what is given by the state.

The principle of public interest is a principle which put the needs of the general public compared to the needs of society or certain groups.

Furthermore, the public interest is also further described in the explanation of Article $49 \mathrm{~b}$ of Law Number 5 of 1986 concerning State Administrative Court which states that the public interest is the "interests of the nation and the State and / or the interests of the community together and / or development purposes, in accordance with the regulations Current regulation".

Based on the above it can be concluded that the definition of public interest is interest that must take precedence over other interests with regard to the proportion of importance and respect other interests.

Should the public interest in the legislation remains formulated in general or broad. When formulated in detail or casuistry in regulation implementation legislation will be stiff, because then bound to the formulation of the Act. General formulation by forming legislation would be more flexible / flexible due to the application or interpretation by the judge based his freedom, can be casually adjusted to the development of society and the state. 
3. Principles of Law as a Tool for Social Engineering

On this principle spelled out the role of law as "a means of social engineering" or a means to determine the desired direction of development of society for the better. Law as a means of social change (law as a tool of social engineering) toward a better legal condition is revealed by Roscoe Pound.

In this Act, the use of the principle of law as a tool of social engineering is very important since the establishment of the Act village consultative body is an effort to change and improve people's habits of limitations become more flexible and sustainable.

Therefore, before a policy is delivered to the public, it is necessary that the mass dissemination of accurate information in order to reconstruct the society and legal awareness baru13. The role of law (regulation legislation) as a means of social engineering to change the style of the society in the conduct important transactions. Their ideas on social change towards the better the right way and is more realistic to encourage people's desire to participate in the mission on social change tersebut14.

${ }^{13}$ Joseph Raz, The Concept of a Legal System: An Introduction to the Theory of Legal System, Oxford: Clarendon Press, 1997, p.165. In the terminology of Raz, initiated legal awareness of some form of prior knowledge that coagulate in memory recall, before ultimately affect personal action and psychological.

${ }^{14}$ Asshiddiqie, Constitutional Economics, Compass January 2010, Jakarta, p 16 


\section{Implementation Practice Nominations, Election, Inauguration and Dismissal of village chief}

1. No provision has been previously

- Law of the Republic of Indonesia Number 6 Year 2014 About the village

- Law of the Republic of Indonesia Number 23 Year 2014 On Local Government

- Law of the Republic of Indonesia Number 9 Year 2015 On the Second Amendment to Law Number 23 Year 2014 on Regional Government

- Indonesian Government Regulation No. 43 2014 On Implementing Regulations of Law No. 6 of 2014 About the village

- Regulation of the Minister of Interior of the Republic of Indonesia Number 1112014 About the Technical Guidelines Rules In the village

- Regulation of the Minister of Interior of the Republic of Indonesia Number 112 of 2014 On the Election of Village Head

- Regulation of the Minister of Interior of the Republic of Indonesia Number 82 Year 2015 On Appointment and Dismissal

Village head

- Regulation of the Minister of Interior of the Republic of Indonesia Number

65 Year 2017 on Amendment Minister Regulation No. 112 of 2014 On the Election of Village Head

- Regulation of the Minister of Interior of the Republic of Indonesia Number

66 Year 2017 on Amendment Minister Regulation No. 82 Year 2015 On Appointment and Dismissal of the Village Head 
2. Importance Socialization regulation candidacy, Selection, Appointment and Dismissal Inaugural Village Head Goal socialization village consultative body that is the whole society ...... District who live in the area of government districts ..... withorientation for utilization sstructures are at law that renewable. Effort socialization carried out to avoid errors in interpreting and practicing the function and purpose of the procedure for the nomination, election, appointment, appointment and dismissal of the head of the villageitself in middle of the community. Socialization strategy that if it can be done through the media of television, social media or face to face, then with thus be expected will happen the transformation of information and knowledge about the nomination, election, pengangkatan, appointment and dismissal of the head of the village

3. Village head

Village governance undergone fundamental changes through the revision of Law No. 32 of 2004, which was replaced by Act No. 6 of 2014 on the village. The amendment is based on historical arguments, philosophical, juridical, and sociological psikopolitik. The arguments are oriented to the effort to organize the village. One of the important issues in structuring the village is the village head filling positions that can not be separated from the institutional design of the village administration.

One substance that Act No. 6 of 2014 regarding structuring institutional arrangements regarding the village is the village, the Village Government institutions composed of village government, Village Consultative Body and the Village Community Institutions. The village government is the village chief who serves as head of the village administration who led the organization of the village administration. Head 
The village has an important role in his capacity as representative of the country close to the community and as a community leader. With such a position, the principle of the regulation of the village chief is:

a) Mentions village head adapted to local designation;

b) The village head serves as the head of the village government and community leadership;

c) The village chief elected democratically and directly by the local community;

d) The candidacy of the head of the village in a direct election does not use political party base so that the head of the village are barred from political party leaders.

According to Law No. 6 of 2014 About the village and Government Regulation No. 43 Year 2014 About the village stated that:

The village is the village and the traditional village or called by other names, hereinafter called the village, is the unity of the legal community who have boundaries that are authorized to regulate and megurus government affairs, the interests of the local community by community initiatives, the right of origin, and / or traditional rights recognized and respected in the government system of the Republic of Indonesia.

The village government is spearheading the local government system related and in direct contact with the public. Therefore, systems and mechanisms of local government administration can not be discharged and is determined by the village government and Village Consultative Body (BPD) as part of the Regional Government as stipulated in Article 371 and Article 372 of Law No. 23 of 2014. 
The institutional structure and working mechanism at all levels of government, particularly the village government should be directed to create a government that is sensitive to developments and changes taking place in society. Law No. 6 of 2014 set a new design of village elections, among others, is

a) implementation of the elections simultaneously throughout the district (under Article 31 paragraph 1); and b) a term of 6 (six) years and can be served at most 3 (three) times in a row. The village head is elected directly by villagers and citizens of the Republic of Indonesia that meets the requirements in accordance with Article 34 of Law No. 6 of 2014 which specifies that:

(1) The village head directly elected by villagers.

(2) Village Head Election is direct, public, free, confidential, honest, and fair.

(3) Village Head Election implemented through the nomination phase, polling, and determination.

(4) In carrying out the village chief election referred to in subsection (2), the selection committee was formed Village Head

Effort to organize the village through the Village Act provides a different setting in the process of village elections among other things:

a) Elections simultaneously in all districts / cities as stipulated in Article 31 paragraph (1);

b) A term of 6 (six) years and can be served at most 3 (three) times in a row and not as stipulated in Article 39 paragraph (1) and (2).

Fundamental considerations village elections simultaneously related to aspects of efficiency and effectiveness. Efficiency considerations meant that the process of village elections will save the budget, time and energy. While the effectiveness pertains to that process 
the election will be able to realize democracy and eliminate the potential conflict that had occurred such as gambling and other negative aspects that always follow the process of village elections. Therefore, it needs a careful study that the process of changing the system, which in this case is a process towards elections simultaneously, to consider aspects of the locality in accordance with the character of the people, the situation in each district. Concurrent elections pose risks heavier so it needs to be calculated and anticipated / prevented the possibility that could happen.

A reality that can not be denied in the implementation of village elections simultaneously is that the end of the tenure village head in general is not the same. In connection with this matter, in accordance with the provisions of Article 40 paragraph (3) of Government Regulation No. 43 of 2014, when the vacancy occurred village chief in village elections simultaneously then regent appointed acting head of the village comes from civil servants in the local government district /city.

Implementation of village elections held corrugated done at most three (3) times within a period of 6 (six) years, with a maximum time interval of 2 (two) years sebagaiman stipulated in Minister of Home Affairs Number 112 of 2014. The regulation requires the Government area to consider Article 4 paragraph (1) Regulation No. 112 of 2014, namely;

a) grouping the expiration of tenure of the village chief in the district / city;

b) local financial capacity; 
c) the availability of civil servants in the district / city that meets the requirements as acting head of the village.

Fundamental change village election process as a consequence of setting the Act requires that local government district village for

issued the new area as a replacement for the old regional regulation is no longer appropriate to the standard norms of the central government.

Normatively, the substance of the constituency headmen regulation contains provisions which include four (4) phases: a) preparation; b) the nomination; c) voting; d) determination. Each stage includes a substance as outlined in Minister Regulation No. 112 of 2014.

In the normative provisions must be adapted to the conditions in the district ...... adjustments are intended to accommodate the characteristics and developing real conditions in accordance with the district community dynamics ...... In addition, many aspects that are not regulated and / or has not been set in concrete by the provisions of legislation as is standard norms issued by the government.

\section{D. impact Restrictions}

Restrictions on occasions when someone would develop their potential at a certain level and the desire to participate and participate in rural development or growth resulted in an increase in efforts to gain legality as one part and the corresponding objectification that has the ability to become a village head. What then 
be impacted by the regulation is a logical consequence as described in the following conditions;

\section{Social aspects}

With the presence of regulations on procedures for the nomination, election, appointment, appointment and dismissal of the head of the village, the community in general will feel the impact as well as for a general election it is for someone who is a candidate for the head of the village will be ready again to prepare to prove their ability understand and follow the rules that already exist. Including segmentation can be done as follows:

Normatively, the substance of local regulations village election can be based on Government Regulation No. 43 of 2014 and Regulation No. 112 of 2014. Broadly speaking, these provisions include four (4) phases: a) preparation; b) the nomination; c) voting; d) penetapan.Pada stage of preparation described in Article 41 of Government Regulation No. 43 of 2014 can be observed as follows:

a. Village Consultative Body notification to the head of the village on the end of the term of office that delivered 6 (six) months before the end of office;

b. an election committee by the village head Village Consultative Body set within

10 (ten) days after notice of the end of the term of office;

c. a final report to the village chief's tenure regent / mayor delivered within 30 (thirty) days after notice of the end of the term of office; 
d. planning costs submitted by the committee to the election of the regent / mayor through the subdistrict head or other title within a period of 30 (thirty) days after the formation of the election committee; and

e. cost of the US approval of regents / mayors within 30 (thirty) days after submission by the committee.

There are two important things that underlie the preparation stage of village elections, which will have implications on the electoral process and the election can not be realized simultaneously. Due to the many tasks that must be carried out by the committee can be found in article

9 Regulation No. 112 of 2014 on village elections as follows:

a. plan, coordinate, organize, supervise and control all phases of the election;

b. plan and propose the election costs to the regent / mayor through the subdistrict head;

c. conduct voter registration and establishment;

d. hold the netting and screening candidates;

e. determine the candidates who meet the requirements;

f. establishing procedures for the implementation of the elections;

g. establishing procedures for the implementation of the campaign;

h. facilitating the provision of equipment, supplies and polling stations;

i. hold the vote;

j. vote count recapitulation result set and announce the election results;

k. determine the candidates elected village chief; and

l. do evaluation and reporting implementation election. 
2. Aspects of law enforcement

Enforcement of the provisions, in this case the law enforcement in the strict sense, ie law enforcement officials efforts to guarantee and ensure that a legal rule as it ought to, anyway require a forced power to ensure that a legal rule is running properly.

\section{E. Imposition of Regional Financial Impact}

1. Preparation Fees Regulations

Costs of preparing the necessary regulation is since the beginning of the drafting of Regulations nomination, election, appointment, appointment and dismissal of the head of the village in the district of ....., the cost of inter-agency discussions, harmonization costs related legislation.

2. Costs Discussion Rules

Fees Regulation discussion nomination, election, appointment, appointment and dismissal of heads of villages in the district include copying and binding ...... Academic Paper and its laws, the cost of preparation of the discussions between the District Government and

District Legislative Council .......

3. The cost of printing the Official Script Regulation nomination, election, appointment and dismissal of the head peantikan villages in the district ....... Costs may include the costs of editing, printing of official documents in the State Gazette and additional gazette, and delivery to the official agencies and community ,

\section{Cost Socialization}

Regulatory arrangements regarding the nomination, election, appointment, appointment and dismissal of the head of the village is something new for most people, so it's generalized socialization 
a vigorous and continuous. Socialization is done should be through various means of media, both print and electronic.

Socialization is done in an entire region or autonomous regions, the cost required is large enough for to be able to reach areas in locations that are difficult to access.

5. Institutional

Institutional preferably by providing authority to the existing institutions. But that is required is that there are costs for coordination among relevant institutions in order to clear the roles and functions of each institution in the implementation rules for the nomination, election, appointment, appointment and dismissal of the head of the village will be many agencies since the implementation, monitoring and enforcement.

\section{F. Positive impact}

The presence of regional regulation on procedures for the nomination, election, appointment, appointment and dismissal of the Head of the Village will provide certainty and uniformity throughout the village election district .......

The positive impact to be gained is opening up opportunities for all communities to be directly involved in the process of village elections. Education Indonesia will start the democratic life of the village level and if it can succeed then will into miniature democracy national. Communities will get their own selection of village heads. With presence regulation Area this will give positive impact on the government of the village where they will work professionally with carrying out their respective functions each in accordance with the regulations This area. 
From the perekonomoian will give a positive impact on society with some of the activities in the process of selecting the chief. The campaign activities will provide opportunities for traders and other economic players such as printing.

\section{G. Negative impact}

Political education is still minimal in the villages will have a negative effect in the presence of the democratic process in the village. The split in the community would overshadow the village of village head election process. immaturity and excessive ambition by the candidates will be the trigger a split in the community 


\section{CHAPTER III \\ ANALYSIS AND EVALUATION OF REGULATION LEGISLATION}

- $\quad$ Article 18 Paragraph (6) and Act of 1945

Article 33 Paragraph (1) of the

Performance in the field of formation of legislation in the last 10 years shows an increase in both quality and quantity. It is inseparable from the process of drafting legislation forming an increasingly orderly, focused and measurable, although in terms of time still needs to be accelerated without reducing the quality of the norm of law. Acceleration of the settlement of a product of legislation needs to be pushed against the formation program of legislation for the realization of strategic development programs.

Delivery of most of the authority of government to local government, the local government has put at the forefront of national development, in order to create prosperity for the people in a fair and equitable. In this regard the role and regional support for the implementation of laws and the formation of strategic undanagan, particularly in regional regulations (Perda) and other local regulations in accordance with the provisions of the legislation.

Local regulations as a means of regulation of national legislation has a constitutional basis and the juridical basis to the regulation of the position of local regulations in the 1945 Constitution Article 18 paragraph (6) which states that local governments have the right to set regional regulations and other regulations for implementing regional autonomy and co-, In this regard, the national legal systems provide attributive authority to the regions to establish regional Rules and Regulations other, and regulation area be expected could synergistically to support government programs in the area. Local regulations as well as other legislation have function for consummate certaintylaw (Rechtszekerheid, legal certainty). For the proper functioning of the legal certainty undanagn Laws must meet certain conditions, among others consistently in the formulation in which the legislation must be maintained the same systematic relationship 
between maxims, kebakuan composition and language, and the harmonization of relations between the various laws invitation.

Pengharmonisasian legislation lacked urgency in relation to the principle of legislation lesser must not conflict with the laws and regulations are higher, so fundamental to the preparation of the draft local regulations is conformity and kesinkronannya with laws and other invitees.

- Law of the Republic of Indonesia Number 12 Year 2011 concerning the Establishment Regulation Legislation

Rule of law is the basis of state countries whose governments are subject to the law, particularly the Law. Experts distinguish between ordinary Act in the sense of material (wet it materiele zin) and Law in formal sense (this wet formele zin). Understanding Law in the material sense it concerns legislation in terms of the content, material and substance while the Act in formal sense in terms of shape and formation. The distinction both can be seen only in terms of emphasis or angle of vision, which is an Act can be viewed in terms of the material or in terms of its form, which can be seen as two completely separate things. For example, the shape is an egg but the contents of tempeh.

According to IC van der Vies, the issue of how an Act to be made, especially regarding the conditions that must be fulfilled by the makers of the Act. These requirements can be summarized as "the principles of good lawmaking". These principles are concerned with various aspects of the rulemaking, the principles relating to the "how" and the principles relating to the "what" of a decision that each of the so-called principles of formal and material principles ,

Based on the opinions and conditions mentioned above will put forward some views and analysis of Act No. 12 of 2011 Concerning the Establishment Regulation Legislation (Law). In general, the content of the Act can be said is a must (obligatere) so that all the provisions in the Act 
laws must be implemented. If the Act is not implemented this Act can be said to be authoritative.

In Article 5 of the Law states that in the form of legislation should be based on the principles of Regulation Establishment of good legislation, which includes:
a. clarity of purpose;
b. institutional or forming proper authorities;
c. correspondence between the types, hierarchy, and material content;
d. can be implemented;
e. usability and kehasilgunaan;
f. formulation clarity; and
g. openness.

Then in Article 6 paragraph (1) of the Act stated that the substantive content of legislation must reflect the principle:
a. aegis;
b. humanity;
c. nationality;
d. kinship;
e. kenusantaraan;
f. Unity in Diversity;
g. justice;
h. equality in law and governance;
i. order and legal certainty; and / or
j. balance, harmony, and harmony.

Furthermore, in Article 6 paragraph (2) states that in addition to reflect the principle referred to in paragraph (1), specific legislation may contain other principles in accordance with the legal field of legislation is concerned.

The second chapter contains the principles of formal and material that must be implemented in the establishment of any regulatory legislation in Indonesia. As previously stated the contents of the Act generally speaking is a must so that in every establishment regulations 
Legislation in Indonesia of those principles must be adhered to without exception whatsoever.

As an Act into law in order to establish rules of Legislation Act can be said to have been good. If only everyone involved in the formation of legislation Legislation want to learn and implement the Act will not have much trouble again especially with the presence of a very detailed annex.

- Law of the Republic of Indonesia Number 6 Year 2014 About the village

- Article 31:

(1) Village Head Election was held simultaneously in all the district / city.

(2) Government District / Municipal elections set policies simultaneously Village Head as referred to in paragraph (1) Regulation regencies / cities.

(3) Further provisions on the procedure of electing the village chief in unison as referred to in paragraph (1) and (2) regulated by or based on Government Regulation.

- Article 32:

(1) Village Consultative Body inform the village chief about the expiration of tenure of the village chief in writing 6 (six) months before his term ends.

(2) Village Consultative Body shaping Village head of the election committee.

(3) Village head of the election committee as referred to in paragraph (2) shall be independent and impartial.

(4) Village head of the election committee as referred to in paragraph (3) shall comprise village officials, community organizations, and community leaders Village.

- Article 33:

Village Head candidate must fulfill the following requirements:

a. citizens of the Republic of Indonesia;

b. fear of God Almighty;

c. hold firm and practice Pancasila, implement Constitution Basic Country Republic 
Indonesia Year 1945, as well as maintain the integrity of the Unitary Republic of Indonesia and Unity;

d. educated most low graduate school secondary The first or the equivalent;

e. aged at least 25 (twenty five) years at the time of registering;

f. willing to be nominated to be Chief of the Village;

g. registered as a resident and reside in the local village least one (1) year prior to enrollment;

h. not serving a sentence of imprisonment;

i. never been sentenced to imprisonment by a court decision which has had permanent legal force for committing a criminal offense punishable by imprisonment for a minimum of 5 (five) years or more, except for five (5) years after completion of a sentence of imprisonment and declare honestly and openly to the public that he or been convicted of crimes and not repeated;

j. not being deprived of their voting rights in accordance with a court ruling has had permanent legal force;

k. able-bodied;

l. never as a village chief for three (3) term; and

m. Other terms are governed by local regulation.

- Article 34:

(1) The village head directly elected by the inhabitants of the village.

(2) Village Head Election is direct, public, free, confidential, honest, and fair.

(3) Village Head Election implemented through the nomination phase, polling, and determination.

(4) In carrying out the village chief election referred to in subsection (2), the selection committee was formed the chief.

(5) The election committee referred to in paragraph (4) shall hold the netting and screening candidates based on the specified requirements, carry out voting, determine the candidates elected village chief, and reported the election of the chief.

(6) Village head election costs charged to the Budget of the Regency / City. 
Article 35:

Villagers referred to in Article 34 paragraph (1) that on polling day election-old village chief 17 (seventeen) years of age or are / have been married designated as a voter.

- Article 36:

(1) Village Head candidate who meets the requirements referred to in Article 33 is set as a candidate for village chief by the village chief election committee.

(2) Village Head candidate that has been set as described in paragraph (1) shall be announced to the public the village in a public place in accordance with the social and cultural conditions of the villagers.

(3) Village Head candidate to campaign in accordance with the social and cultural conditions of the village and the provisions of the legislation.

- Article 37:

(1) Candidates declared elected village chief who is the candidate with the most votes.

(2) Village head of the election committee shall determine the candidates elected village chief.

(3) Village head of the election committee submit names of candidates elected village chief to the Village Consultative Body of 7 (seven) days after the determination of candidates elected Village Head as referred to in paragraph (2).

(4) Village Consultative Body of 7 (seven) days after receiving the report of the election committee submit names of candidates elected village chief to the Regent / Mayor.

(5) Regent / Mayor endorse candidates elected Village Head as referred to in paragraph (3) into the village chief no later than 30 (thirty) days from the date of receipt of the submission of the election results of the election committee in the form of decisions Village Head of Regent / Mayor.

(6) In case of dispute the election results Village Head, Regent / Mayor shall settle the dispute within the period referred to in paragraph (5).

- Article 38:

(1) Candidates elected village chief was sworn by the Regent / Mayor or his representative not later than 30 (thirty) days after the issuance of the decision Regent / Mayor.

(2) Before taking office, elected village chief swear / promise. 
(3) Oath / pledge as referred to in paragraph (2) as follows: "By Allah / God, I swear / promise that I will fulfill my duty as head of the village as well as possible, truthfully, and seadil- possible; that I will always be obedient in practice and maintain Pancasila as the state; and that I will uphold the Constitution and the democratic life of the Republic of Indonesia Year 1945 and implement all laws and regulations with selurus-righteous that apply to the village, the area, and the Republic of Indonesia ".

- Article 39:

(1) Village Head held the position for six (6) years from the date of appointment.

(2) Village Head as referred to in paragraph (1) may be served at most three (3) term consecutive or not consecutive.

- Article 40:

(1) Village Head held the position for six (6) years from the date of appointment.

(2) Village Head as referred to in paragraph (1) may be served at most three (3) term consecutive or not consecutive. The village head is dismissed as referred to in paragraph (1) c for:

a. end of his tenure;

b. unable to carry out tasks on an ongoing basis or remains incapacitated consecutively for six (6) months;

c. no longer qualify as a candidate for village chief; or $d$. violates the prohibition as the chief.

(3) Dismissal of the Village Head as referred to in paragraph (1) shall be determined by the Regent / Mayor.

(4) Further provisions concerning the dismissal of the Village Head as referred to in paragraph (1) shall be regulated in Government Regulation.

- Article 41:

Village head suspended by the regent / mayor once declared the defendant punishable by imprisonment for a minimum of 5 (five) years based on the register of a court. 
- Article 42:

Village head suspended by the Regent / Mayor once identified as suspects in corruption, terrorism, treason, and / or a crime against state security.

- Article 43:

The village head who has been suspended as referred to in Article 41 and Article 42 dismissed by the regent / mayor after being declared as a convict under a court decision has had permanent legal force.

- Article 44:

(1) The head of the village who has been suspended as referred to in Article 41 and Article 42 after going through the judicial process proved innocent by a court decision that has had permanent legal force, not later than 30 (thirty) days after the establishment of the court decision is accepted by the Village Head, Regent / Mayor rehabilitate and reactivate the village chief is concerned as village chief until the end of his term.

2 ) If the village chief who has been suspended as referred to in paragraph (1) has ended its tenure, the Regent / Mayor shall rehabilitate the good name of the village chief is concerned.

- Article 45:

In the case of the village chief suspended as referred to in Article 41 and Article 42, the secretary of the village of performing its duties and obligations of the Village Head up to the court ruling which has had permanent legal force.

- Article 46:

(1) In case the remaining term of the village chief who dismissed as referred to in Article 43 is not more than 1 (one) year, Regent / Mayor raised the civil servants of the Local Government 
Regency / City as acting head of the village up to the election of the chief.

(2) Acting Village Head duties, powers, obligations and rights of the Village Head as referred to in Article 26.

- Article 47

(1) In case the remaining term of the village chief who dismissed as referred to in Article 43 is more than 1 (one) year, Regent / Mayor raised the civil servants of the Regional Government of Regency / City as acting head of the village.

(2) Acting Village Head as referred to in paragraph (1) carry out the duties, powers, obligations and rights of the Village Head as referred to in Article 26 until the enactment of the chief.

(3) Village Head as referred to in paragraph (2) is selected through the Village Council that the requirements referred to in Article 33.

(4) Village Consultation referred to in paragraph (3) shall be implemented not later than six (6) months after the village chief was dismissed.

(5) The village head is selected through the Village Council referred to in paragraph (3) carry out tasks Village head until the end the term of the village chief who was dismissed.

(6) Further provisions on the Village Council referred to in paragraph (3) shall be regulated in Government Regulation.

- $\quad$ Law of the Republic of Indonesia Number 23 Year 2014 On Local Government

In carrying out the authority of the government affairs area, Regional Head and DPRD as administrators of the region make the legislation as the basis for the Law of the Regions in conducting a regional autonomy in accordance with the conditions and aspirations and the uniqueness of the area. Bylaw made by the Region only valid within the limits of the jurisdiction of the relevant region.

Nevertheless regulations set by the region must not conflict with the provisions of the Legislation of a higher order in accordance with the hierarchy 
legislation. Besides regulation as part of a system of laws and undanagan should not be contrary to public interest as stipulated in the rules of lawmaking.

Regions to implement regional autonomy which came from the authority of the President of the power of government. Given the ultimate responsibility for governance is in the hands of the President, it is a logical corollary of the authority to cancel the regulation is in the hands of the President. Is not efficient when the President who immediately cancel the decision. President of the Provincial Regulation cancellation delegate authority to the Minister as assistant to the President in charge of Autonomy. As for the regulation cancel Regency / City, the President delegated his authority to the Governor as the Vice President of the Central Government in the Region.

To avoid arbitrariness in the cancellation of the decision, the Provincial Government may appeal the cancellation of the Provincial Regulation made by the Minister to the President. While the District Government / City Bylaw may appeal the cancellation of the Regency / City conducted as deputy governor of the central government to the Minister. In terms of the regional administration, the decision taken by the President and the Minister brersifat final.

In order to create orderly administration reporting legislation, every regulation that will be promulgated shall obtain a registration number in advance. Provincial Local regulations must obtain a registration number from the ministry, while the regulation District / City get a registration number of the governor as a representative of the central government. With the existence of the registry number will accumulate information on the overall regulation formed by the Region and at the same time as national regulation information. 


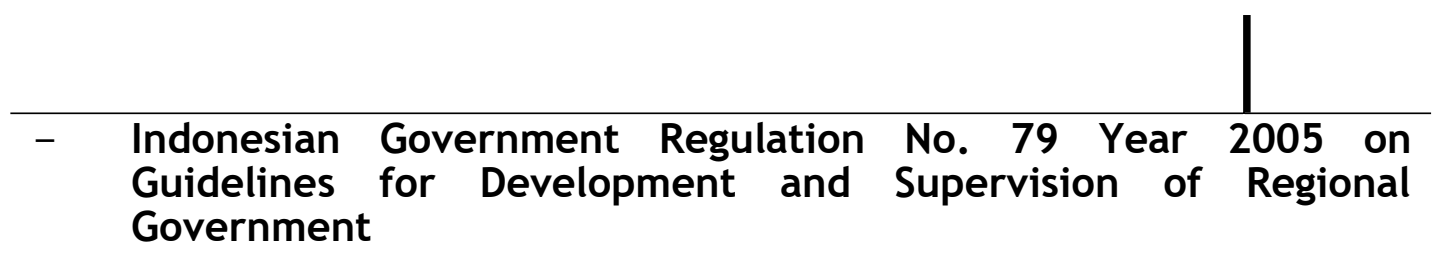

Regional Government is essentially a sub-system of the national government and implicitly guidance and supervision of the Regional Government is an integral part of the system of governance. Legislative Council which is the representative body of the people as a component of the Local Government and are domiciled similar partnerships with local governments. Guidance on the regional administration is the effort made by the government and / or Governor as representative of the government in the region to realize the achievement of the objectives of regional autonomy, including government coordination between levels of government, the provision of guidelines and standards implementation of government affairs, provision of guidance, supervision and consulting implementation government affairs,

Guidance on local government processes implemented by the government include:

1. Coordination of government over the composition of the government with regard to aspects of the planning and evaluation of the implementation of governance in the region.

2. Provision of guidelines and standards implementation of government affairs covers all aspects of planning, implementation, governance, funding, quality, control and supervision.

3. Provision of guidance, supervision, and consultation implementation of government affairs Covering all aspects of planning, implementation, governance, funding, quality, control and supervision.

4. Includes training and education clump substantive technical education and training of local government and education and functional training for the post - functional target Affairs Department.

5. Planning, research, development, monitoring, and evaluation of the implementation of government Includes long-term planning Medium-term planning and annual planning based pertaturan law - law. And also includes institutional authority, personnel, finance, asset management, Apartment NonGovernment Institutions, Regional Representatives Council, public services, and regional policy.

Supervision of the implementation of government affairs in 
the area include:

1. Implementation of government affairs at the provincial Covers the implementation of local government affairs mandatory, choice, and according to the principles of deconcentration and assistance. Coordinated by the General Inspectorate of the Interior.

2 Implementation of government affairs at the district / city government affairs area covers the implementation of a compulsory, choice, and according to the principle of coadministration. Coordinated by the Provincial Inspectorate.

3. Pelaksaanaan government affairs at the village Coordinated by the Inspectorate district / city.

Guidance on the regional administration is the effort made by the government and / or Governor as representative of the government in the region to realize the achievement of the objectives of regional autonomy. Government supervision over the region by the government, governors and regents / mayors are kegiatanyang process aimed at menjaminagar the regional administration and the village went according to plan and the provisions of laws

-invitation. Supervision is done by the internal forces of government in accordance with their respective authorities. In addition to the supervision of supervision by society (social control) is required dala realize the role of the community in order to create an effective governance, efficient, streamlined, clean and free from corruption, collusion and nepotism.

In order to optimize the function of management and and supervision Penerintah give awards to the regional government, the head of the Regional and or deputy regional head legislators, local apparatus, civil service area, the village head, village and limbs deliberations village based on the results of an assessment of the implementation of government affairs area that shows specific achievements. Instead the government to sanction them if found any irregularities and violations. 
- Indonesian Government Regulation No. 43 Year 2014 About the Implementing Regulations of Law No. 6 of 2014 About the village

- Article 40:

(1) The village head elections held simultaneously in all districts / cities.

(2) The village head elections simultaneously as referred to in paragraph (1) may be carried out bumpy at most three (3) times within a period of 6 (six) years.

(3) In case of vacancy of the village chief in the administration of the village head elections simultaneously, the regents / mayors appoint the acting head of the village.

(4) Acting head of the village as referred to in paragraph (3) is derived from the civil servants in the local government district / city.

- Article 41:

(1) The village head election is carried out through the following stages:

a. preparation;

b. nomination;

c. voting; and

d. determination.

(2) Stages of preparation as described in paragraph (1) letter a comprise the following activities:

a. Village Consultative Body notification to the head of the village on the end of the term of office that delivered 6 (six) months before the end of office;

b. an election committee by the village head Village Consultative Body set within

10 (ten) days after notice of the end of the term of office;

c. a final report to the village chief's tenure regent / mayor delivered within 30 (thirty) days after notice of the end of the term of office;

d. planning costs submitted by the committee to the election of the regent / mayor through the subdistrict head or other title within a period of 30 (thirty) days after the formation of the election committee; and

e. cost of the US approval of regents / mayors within 30 (thirty) days after submission by the committee.

(3) Stages as referred to in paragraph (1) letter b shall consist of the following activities:

a. announcement and registration of candidates within a period of nine (9) days;

b. research administration requirements, clarification, and the determination and announcement of the names of candidates within a period of 20 (twenty) days;

c. The village head candidate determination as referred to in paragraph b of at least 2 (two) and no more than five 
(5) candidates;

d. the determination of the final voters list for the election of village heads;

e. The village head candidate campaign execution within a period of three (3) days; and

$\mathrm{f}$. quiet period in the period of 3 (three) days.

(4) Stages voting referred to in paragraph (1) letter c consists of the following activities:

a. implementation of the voting and counting;

b. determination of the candidate with the most votes; and / or

c. in the case of candidates who obtain the largest number of more than 1 (one), the elected candidate is determined based on the area acquisition wider sound.

(5) Stages of the determination referred to in paragraph (1) letter $\mathrm{d}$, it consists of:

a. reports the election committee of the candidates elected to the Village Consultative Body no later than seven (7) days after the vote;

b. Village Consultative Council report on candidate elected to the regent / mayor no later than 7 (seven) days after receiving the committee report;

c. regent / mayor issued a decree on the ratification of the appointment of the head of the village and at the latest 30 (thirty) days from the receipt of the report of the Village Consultative Body; and

d. regent / mayor or other officials appointed by elected village head candidate induct at least 30 (thirty) Days since the decision issued ratification and appointment of village heads to the procedure in accordance with laws and regulations.

(6) Another designated official referred to in paragraph

(5) d is deputy regent / mayor or subdistrict or other designations.

(7) In case of dispute the election results village head, regents / mayors shall settle the dispute within a period of 30 (thirty) days.

- Article 42:

(1) The village head, who will run back given leave from the set as candidates until the completion of the determination of selected candidates.

(2) In the case of the head of the village leave referred to in paragraph (1), the secretary of the village of performing its duties and obligations of the village head.

- Article 43:

(1) Civil servants who run for village heads must obtain written permission from the staff development officer.

(2) In the case of civil servants referred to in paragraph (1) 
elected and appointed head of the village, which concerned exempted temporarily from his post for the head of the village without losing rights as civil servants.

- Article 44:

(1) Village officials who ran in the election of village heads were given time off since the respective registered as candidates for the head of the village until the completion of the determination of selected candidates.

(2) Task Village devices referred to in paragraph (1) is held by a device other village established by decision of the village head.

Article 45:

The village held deliberations on the implementation of the interim village held elections at the latest within a period of six (6) months from the village chief was dismissed with the following mechanism:

a. prior to the deliberation Village, activities include:

1. an election committee head intertemporal Village by Village Consultative Body at the latest within a period of 15 (fifteen) days commencing from the village chief is dismissed;

2. filing fee with the burden of APB village election by the election committee to the acting head of the village at the latest within 30 (thirty) days since the committee was formed;

3. costs of approval by the acting head of the village elections at the latest within 30 (thirty) days since filed by the election committee;

4. announcement and registration of candidates by the village head of the election committee within a period of 15 (fifteen) days;

5. research administration requirements of candidates by the election committee within seven (7) days; and

6. The village head candidate determination over time by the election committee at least two (2) candidates and a maximum of three (3) candidates who sought endorsement for the village deliberation designated as eligible candidates selected in village meetings.

b. Village Consultative Body held a village meeting that includes the following activities:

1. organizing village meetings chaired by the Chairman of the Village Consultative Body which is the technical implementation of the election conducted by the election committee;

2. ratification of the village head candidate is entitled chosen by village meetings through consensus or by 
voting;

3. the election of the village head candidate by the election committee through the mechanism of consensus or by voting as agreed by village meetings;

4. reporting the results of the selection of candidates by the village head to a village meeting of the election committee;

5. endorsement of candidates elected by village meetings;

6. reporting the results of elections to the village through village meetings Village Consultative Body within

7 (seven) days after village meetings endorse candidates elected village head;

Article 47:

(1) Village Head held the position for six (6) years from the date of appointment.

(2) Village Head as referred to in paragraph (1) may serve a maximum of three (3) term consecutive or not consecutive.

(3) Periodization of tenure provisions referred to in paragraph (2) shall apply in the entire territory of Indonesia.

(4) Periodization of tenure provisions referred to in paragraph (2) including a term of elected village head through village meetings.

(5) In the case of the village chief to resign before his term runs out or dismissed, the village head is deemed to have served one (1) the period of tenure.

Article 54:

(1) The village head stops for:

a. die;

b. own request; or

c. dismissed.

(2) The village head is dismissed as referred to in paragraph

(1) c for:

a. end of his tenure;

b. unable to carry out tasks on an ongoing basis or remains incapacitated consecutively for six (6) months;

c. no longer qualifies as a village head;

d. violates the prohibition as the head of the village;

e. the status change into urban villages, merging two (2) or more villages into 1 (one) new villages, or the elimination of the village;

f. discharge duty as the head of the village; or

g. expressed as a convict under a court decision has had permanent legal force.

(3) If the head of the village stopped as referred to in 
paragraph (1), Village Consultative Body to report to the regent / mayor through the subdistrict head or other designations.

(4) Dismissal of village head referred to in paragraph (3) shall be determined by the decision of the regent / mayor.

- Article 55:

In case the remaining term of the village head that stops not more than 1 (one) year since dismissed as

referred to in Article 54 paragraph (1) letter a and letter b and paragraph (2) b, c, d, f, and g, regent / mayor raised civil servants from local government district / city as acting chief village until the election of the new village head

Article 56

In case the remaining term of the village chief who quit more than 1 (one) year since dismissed as referred to in Article 54 paragraph (1) letter a and letter b and paragraph (2) b, c, d, $\mathrm{f}$, and g, regent / mayor raised civil servants from local government district / city as the acting head of the village until the election of the new village head through the results of community meetings.

- $\quad$ Article 57

(1) In the event of delay in implementation of the policy of village elections, village heads outgoing fixed and subsequently dismissed regents / mayors raised the acting head of the village.

(2) Policies postponement of village elections referred to in paragraph (1) shall be determined by the Minister.

(3) Regent / mayor raised the acting head of the village as referred to in paragraph (1) of the civil servants of the local government district / city.

Article 58:

(1) Civil servants who are appointed as acting head of the village as referred to in Article 55, Article 56 and Article 57 paragraph (3) at least have to understand the technical areas of leadership and governance.

(2) Acting head of the village as referred to in paragraph (1) carry out the duties, powers, and obligations and obtain the same rights as the village head. 
Article 59:

(1) Village head with the status of civil servants when quitting as head of the village returned to their parent institutions.

(2) Village head with the status of civil servants when it has reached the retirement age of civil servants dismissed as respectfully as civil servants to acquire rights in accordance with the provisions of the legislation.

- $\quad$ Regulation of the Minister of Interior of the Republic of Indonesia Number 112 of 2014 On the Election of Village Head

As with other regulations, on Permendagri

112 In 2014, First Section of Chapter I also discussed the general provisions which must be lived in the village elections. One is on the executive committee village elections, as outlined in chapter 1 item 7, 8, and 9 of this;

- Village head of the election committee village level, hereinafter referred to the Election Committee is the committee formed by the BPD to organize the village head elections;

- Village head of the election committee at the district / city hereinafter called Election Committee Regency / City is the committee that established the Regent / Mayor at the regency / city in support of the village chief elections.

- Candidate Village Head is the village chief candidates established by the selection committee as a candidate has the right to be elected as head of the village;

In Chapter II have been included in the provisions on the election of the village head. There explained that the implementation of village elections can be held simultaneously in an area or can also be bumpy. Simultaneously means held on the same day and time and in unison, while in waves based on the consent and agreement has been reached, both by the election committee or other relevant parties.

As the elections are held simultaneously, the election of village chief in waves 
also based on various reasons. It was as set out in Article 4:

- Village Head Election in waves as referred to in Article 2 may be implemented with respect to:

- $\quad$ grouping the expiration of tenure of the village chief in the district / city;

- local financial capacity; and / or

- the availability of civil servants in the district / city that meets the requirements as acting head of the village.

Apart from being the earliest, chapter 6 being part of the set "implementation" Village head election. Among these are the set of stages of the village head elections, which includes the preparation of nomination, voting, determination.

Article 7 of Regulation No. 112 of 2014 contains on initial activities that must be carried out ahead of the implementation of village elections. Here are some of the provisions as quoted on the points contained in chapter 7;

- notification village consultative body to the village head on the end of the term of office that delivered 6 (six) months before the end of office;

- an election committee head of the village by village consultative body set within a period of ten (10) days after notice of the end of the term of office;

- a final report tenure village head to the regent / mayor delivered within 30 (thirty) days after notice of the end of the term of office;

- planning costs submitted by the committee to the election of the regent / mayor through the subdistrict head or other title within a period of 30 (thirty) days after the formation of the election committee; and

- cost of the US approval of regents / mayors within 30 (thirty) days after submission by the committee.

Some of the tasks to be carried village chief election committee has been set in accordance with Article 9 Regulation of the Minister of Interior No. 112 le;

1. plan, coordinate, organize, supervise and control all phases of the election;

2. plan and propose the election costs to the regent / mayor through the subdistrict head;

3. conduct voter registration and establishment; 


\section{Article}

4. hold the netting and screening candidates;

5. determine the candidates who meet the requirements;

6. establishing procedures for the implementation of the elections;

7. establishing procedures for the implementation of the campaign;

8. facilitating the provision of equipment, supplies and polling stations;

9. hold the vote;

10. set result recapitulationcalculation sound and announced the results of the election;

11. determine the candidates elected village chief; and

12. evaluating and reporting the implementation of election

The next chapter, that chapter 10 is the chapter that regulates voters are eligible to vote for the sake of determining the village head.

The provisions stating the validity of these voters are listed at length and clear from Article 10 to Article 20.

Article 21, an important requirement for candidates who want to run for any nominated. There are more than ten grains of conditions to be met, following more;

1. citizens of the Republic of Indonesia;

2. fear of god almighty one;

3. uphold and practice Pancasila, implement the basic law of the republic Indonesia in 1945, as well as maintain the integrity of the unitary state of Indonesia and Unity;

4. most low-educated junior high school graduate or equivalent;

5. aged at least 25 (twenty five) years at the time of registering;

6. willing to be nominated to be the head of the village;

7. registered as resident and domiciled in the local village least one (1) year prior to enrollment;

8. not serving a criminal sentencejail;

9. never been sentenced to imprisonment by a court decision that has had permanent legal force for a criminal offense punishable by imprisonment for a minimum of 5 (five) years or more, except for five (5) years after completion of a sentence of imprisonment and declare honestly and openly to the public that the individual concerned and not been convicted of crimes over and over re;

10. not being deprived of their voting rights in accordance with a court ruling has had permanent legal force;

11. able-bodied;

12. never as a village chief for three (3) term; and 


\section{Article}

13. Other terms are governed by local regulation.

Just as we often see during the presidential elections, the village head elections also provided time to campaign for their candidates. Vision and mission becomes essential to put forward in order to attract sympathy. Well provisions in village election campaign mentioned in article 29 is:

The campaign referred to in Article 27 paragraph (1) may be implemented through:

- closed meeting;

- face to face

- dialog;

- $\quad$ Campaign materials dissemination to the public;

- $\quad$ installation of props in the campaign and in other places that are determined by the selection committee; and

- $\quad$ other activities that do not violate laws and regulations.

Regarding the elections and campaigns are described from chapter 27 to chapter 31, while article 32 contains the quiet period, which also testified that three days ahead of the day of voting is to be a quiet period.

Guidance regarding voting and counting written in the Regulation No. 112 of 2014 article 33 to article 43. There are many mechanisms described there. In addition to election time, there is also a requirement for the election of people with special needs (disabilities), those who were hospitalized, the provisions of the existence of the TPS, and many more.

Rules implementing village elections in Chapter III of the fifth section which is also a section 44 consists of three paragraph. Loading of the determination of the village head, in which the parties describe as the subject of such determination. The related parties of which is the Village Head Election Committee, BPD (Village Consultative Body), and the Mayor / District Head.

Chapter $\mathrm{V}$ about financing, Consists of one article (ie section 48) and two paragraphs, following more contents;

1. Village head election costs charged to the Budget of the 
Article

Regency / City.

2. A grant from the Rural Income and Expenditure Budgets for the needs of the polls.

Regulation of the Minister of Interior of the Republic of Indonesia Number 82 Year 2015 On Appointment and Dismissal of the Village Head

Section 2:

(1) The village head is the head of the village administration that led the implementation of the Government and as perpanjangantangan country village close to the community as well as community leaders.

(2) Implementation of Village Government referred to in paragraph (1) shall be organized by the village government.

(3) The village government referred to in paragraph (2) is the village chief is assisted by the Village.

(4) Village Head as referred to in paragraph (3) charge of organizing the Village Administration and implement village development, community development, and community empowerment.

Article 3:

(1) Candidates elected village chief appointment ratified by the Decree of the Regent / Mayor.

(2) Decree of Regent / Mayor referred to in paragraph (1) shall be issued no later than 30 (thirty) days after the receipt of the report the election results Village Head of BPD.

(1)

(2) Candidates inauguration elected village chief made no later than 30 (thirty) days from the published decision of the Regent / Mayor on ratification of the appointment of elected village chief.

(3) Inauguration candidate elected Village Head as referred to in paragraph (1) conducted by Regent / Mayor or his representative.

(4) The composition of the inauguration of the Village Head as referred to in paragraph (1) are as follows:
a. Reading Decision Regent / Mayor about Ratification of the appointment of the chief.
b. Taking Oath / Promise office by
Regent / Mayor or his representative.
c. signature
/ pledge.


Article

d. Said the inauguration by the regent / mayor or a designated official.

e. Embedding the mark positions by regent / mayor or a designated official.

f. Mandate readings Regent / Mayor.

g. Chanting prayers

(5) In addition to the official inauguration as referred to in paragraph

(3) the village authorities and communities can organize social activities in accordance with the local culture whose implementation further stipulated in the Regulation of Regent / Mayor.

Article 5:

(1) Handover is done after the inauguration candidate elected village chief.

(2) Handover referred to in paragraph

(1) implemented with the signing of the minutes of the handover.

(3) The signing of the minutes of the handover as described in paragraph (2) shall be implemented at the swearing-in event / appointment and inauguration candidates elected village chief positions after embedding the mark in conjunction with memory handing handover.

(4) Memory handover referred to in paragraph (3) shall consist of: $a$. Introduction b. The village monograph $c$. Implementation of the work program last year $d$. Plan future programs e. Activities that have been completed, are being implemented and action plans last year. f. Barriers faced. g. List of inventory and wealth of the village 
Article

(1) Village Head stopped because: a. Die; b. Own request; or c. Dismissed.

(2) The village head is dismissed as referred to in paragraph

(1) c for:

a. End of his tenure;

b. Unable to carry out tasks on an ongoing basis or remains incapacitated consecutively for six (6) months;

c. No longer qualifies as a village head;

d. Violating the ban as the head of the village;

e. The change of status of the village into the village, the combination of 2 (two) or more villages into 1 (one) new village, or the elimination of the village;

f. Do not carry out duties as head of the village; or

g. Expressed as a convict under a court decision has had permanent legal force.

(3) If the head of the village stopped as referred to in paragraph (1), Village Consultative Body to report to the Regent / Mayor through camat or other designations.

(4) Chairman of the Village Consultative Body reports to the Regent / Mayor referred to in paragraph (3) contain materials that situation happened to the village chief is concerned.

(5) Leader report on Village Consultative Body as referred to in paragraph (4) Regents / Mayors conducted a study for the next process.

Article 9:

Head Village could dismissed while by

Regent / Mayor as:

a. Do not carry out duties as head of the village;

b. Violating the ban as village chief;

c. Expressed as a defendant shall be sentenced to imprisonment for five (5) years based on the register of a court; and

d. Identified as suspects in corruption, terrorism, treason, and / or a crime against state security.

Article 10:

(1) Ratification of the dismissal of the Village Head as referred to in Article 8 paragraph (1) shall be determined by the Decree of the Regent / Mayor. 
(2) Decree of Regent / Mayor referred to in paragraph (1) shall be addressed to the Head of the village concerned and relevant officials at the provincial and regency / city.

- Regulation of the Minister of Interior of the Republic of Indonesia Number 65 Year 2017 on Amendment Minister Regulation No. 112 of 2014 On the Election of Village Head

Several provisions in Regulation of the Minister of the Interior No.

112 of 2014 on the Election of Village Heads (Official Gazette of the Republic of Indonesia Year 2014 No. 2092) shall be amended as follows:

- Article 4:

(1) Village elections in waves as referred to in Article 2 may be implemented with respect to: a. grouping the expiration of tenure of village heads in the district / city; b. local financial capacity; and / or c. the availability of civil servants in the local government district / city that meets the requirements as acting head of the village.

(2) Village elections in waves as referred to in paragraph (1) shall be at most three (3) times within a period of 6 (six) years.

(3) Further provisions on the time interval in waves village election referred to in subsection (2) is regulated by the Regent / Mayor.

- Article 5:

(1) Regent / mayor form an election committee at the district / city are determined by decision of the regent / mayor.

(2) The task of the election committee at the district / city referred to in paragraph (1) shall include:

a. plan, coordinate and conducting all phases of the electoral district / city level;

b. conduct technical guidance to the village head elections committee village level the village head elections;

c. set the number of ballots and ballot boxes;

d. facilitate printing of ballot papers and ballot boxes as well as the manufacture of other election paraphernalia;

e. deliver ballots and ballot boxes and other election paraphernalia to the election committee; 
f. facilitate the settlement of problems of the village head election district / city level;

g. to supervise the implementation of village elections and to report and make recommendations to the regent / mayor; and $\mathrm{h}$. evaluating and reporting on the implementation of elections.

(3) The task of the election committee as referred to in paragraph

(2) c, d and e of implementation can be assigned to the village which is regulated by the Regent / Mayor.

\section{Article 21:}

Village head candidate must fulfill the following requirements:

a. citizens of the Republic of Indonesia;

b. fear of God Almighty;

c. uphold and practice Pancasila, implement the constitution of the republic of Indonesia Year 1945, as well as maintain the integrity of the Unitary Republic of Indonesia and Unity;

d. most low-educated junior high school graduate or equivalent;

e. aged at least 25 (twenty five) years at the time of registering;

f. willing to be nominated to be the head of the village;

g. deleted;

h. not serving a sentence of imprisonment;

i. never been sentenced to imprisonment by a court decision which has had permanent legal force for committing a criminal offense punishable by imprisonment for a minimum of 5 (five) years or more, except for five (5) years after completion of a sentence of imprisonment and declare honestly and openly to the public that he or been convicted of crimes and not repeated;

j. not being deprived of their voting rights in accordance with a court ruling has had permanent legal force;

k. able-bodied;

l. never as the head of the village for three (3) term; and

$\mathrm{m}$. Another condition stipulated in the regulations of Regions.

Article 42:

(1) Village head candidate who gets the most votes from the number of valid votes is set as a candidate for elected village head.

(2) In the case of the village head candidate who gets the most votes of more than 1 (one), the elected candidate 
determined based on the area of acquisition of valid votes wider.

(3) Implementation of the acquisition of valid votes wider referred to in paragraph (2) shall be governed by the rules regent / mayor.

Article 47A:

(1) Village Head who stops and / or terminated with a remaining term of more than one year, regents / mayors raised civil servants from local government district / city as the acting head of the village until the village chief is set between the time the results of community meetings.

(2) Village Consultation referred to in paragraph (1) shall be implemented not later than six (6) months after the village chief was dismissed.

(3) The term of office stipulated village head through village meetings since the date of appointment until the run out the remaining term of the village chiefs dismissed.

Article 47B:

(1) BPD village election committee formed over time.

(2) Establishment of village election committee between the time referred to in paragraph (1) shall be determined by the decision of the leadership of BPD.

(3) The village head election committee consists of the time between the village and the public.

(4) Village election committee between the time referred to paragraph (3), the numbers are adjusted to the workload and the ability of the village government budget.

(5) Village election committee between the time referred to paragraph (4) is responsible to the leadership of BPD.

Article 47C:

(1) The election committee referred to in Article 47B paragraph (3) do the crawl and screening candidates for village chief over time.

(2) Screening candidates become candidates for village chief village head set at least two (2) candidates and a maximum of three (3) candidates.

(3) In terms of the number of candidates as referred to in paragraph

(2) that meets the requirements of more than 3 (three), the committee undertake additional selection. (4) Selection 
Additional referred to in paragraph (3) shall consist of:

a. have experience of the village administration;

b. level of education; and / or

c. Additional requirements are set regent / mayor.

(4) In the case of candidates who meet the requirements of less than 2 (two), the election committee to extend the registration period for 7 (seven) days.

(5) In the case of candidates who meet the requirements remain less than 2 (two) after an extension of time referred to in paragraph (4), BPD postpone deliberation village village elections until the time set by the BPD.

Article 47D

(1) Village elections across time carried out through the following stages:

a. preparation;

b. implementation; and

c. reporting.

(2) Stages of preparation as described in paragraph (1) shall include:

a. the establishment of inter village election committee by BPD longest time within a period of 15 (fifteen) days from the village chief is dismissed;

b. the cost of filing the election with the burden Budget village by the acting head of the election committee to the longest village within a period of 30 (thirty) days after the committee was formed;

c. costs of approval by the acting village head election at the latest within a period of 30 (thirty) days as proposed by the election committee;

d. announcement and registration of candidates by the village head of the election committee within a period of 15 (fifteen) days;

e. research administration requirements of candidates by the election committee within seven (7) days; and

f. village head candidate determination over time by the election committee at least two (2) candidates and a maximum of three (3) candidates who sought endorsement village meeting to be determined as eligible candidates selected in village meetings 
(3) Stages of implementation referred to in paragraph

(1) letter b shall include:

a. organizing village meetings chaired by the Chairman of the technical implementation of BPD election is done by the election committee;

b. ratification of the village head candidate is entitled chosen by village meetings through consensus or by voting;

c. the election of the village head candidate by the electoral committee and village meeting attendees through the mechanism of consensus or by voting as agreed by village meetings;

d. reporting the results of the selection of candidates by the village head to a village meeting of the election committee; and

e. endorsement of candidates selected by the village meeting.

(4) Participants village meeting referred to in paragraph (3) $c$ involves elements of society.

(5) Community elements referred to in paragraph (4) is derived from:

a. traditional leaders;

b. religious leaders;

c. public figure;

d. education figure;

e. representatives of farmer groups;

f. a representative group of fishermen;

g. a representative group of artisans;

h. representatives of women's groups;

i. representation group observer and protection children;

j. representatives of the poor; or

$\mathrm{k}$. other community elements in accordance with the local social and cultural conditions.

(6) Community elements referred to in paragraph (5) k is represented at most five (5) persons from each village or other designations.

(7) The number of participants village meeting referred to in paragraph (4) and (5) discussed and agreed on with BPD and village governments with regard to the number of people having the right to vote in the village established by decision of BPD.

(8) Stages of reporting referred to in paragraph (1) letter c include:

a. reporting the results of elections to the village through village meetings BPD within 7 (seven) days after village meetings endorsed the elected village head candidate; 
b. elected village head candidate reporting the results of a village meeting by the chairman of the BPD to the regent / mayor no later than 7 (seven) days after receiving the report of the election committee;

c. publishing decision regent / mayor on the ratification of the appointment of elected village chief no later than 30 (thirty) days of receipt of the report of BPD; and

d. inauguration of the head of the village by the regent / mayor later than 30 (thirty) days after the ratification of the appointment of the decision issued elected village head with the inauguration of the order pursuant to laws and regulations.

(9) Phase of the village election between the time referred to in paragraph (2), paragraph (3), and paragraph

(4) can be shortened by considering the efficiency and effectiveness of the implementation is stipulated in Regent / Mayor.

Section 47E:

(1) BPD submit reports village head candidate elected village meeting results to the regent / mayor.

(2) Regents / mayors endorse candidates for elected village head referred to in paragraph (1) the decision of the regent / mayor.

(3) Regent / mayor shall inaugurate the elected village head candidate in accordance with the provisions of the legislation.

Article 48:

(1) Cost of village elections and the election committee assignments districts / cities whose implementation was assigned to the village charged to the budget.

(2) Village elections across time through village meetings APBDesa charged.

- Regulation of the Minister of Interior of the Republic of Indonesia Number 66 Year 2017 on the Amendment of the Regulation of the Minister of

State No. 82 of 2015 On Appointment and Dismissal of the Village Head

Article 1:

1. The village is the village and the traditional village or called by other names, hereinafter called the village, is a unit of community has boundaries that are authorized to regulate and manage the affairs of government, from local interests 
based community initiatives, the right of origin, and / or customary rights recognized and respected in the governance system of the Republic of Indonesia.

2. Village Administration is the implementation of government affairs and public interests in the governance system of the Republic of Indonesia.

3. The village government is the village chief or referred to by other names Villages assisted devices as part of administrators of the Village.

4. The village head is the village government officials who have the authority, duties and obligations to carry out household duties his village and of Government and Local Government.

5. The Village is the element that helps the village chief of staff in policy formulation and coordination of the Secretariat contained in the Village, and the village chief task of supporting elements in the implementation of policies contained in the form of Technical Implementation and territorial element.

6. Budget Village, hereinafter referred to APBDesa the annual financial plan Village Government.

7. Elected Village Head candidate is a candidate for village chief who gained the most votes in a village head elections.

8. The court verdict is a statement the judge pronounced in open court, which can be either a criminal prosecution or a free or free from all charges.

9. The suspect is a man who because of his actions or conditions based on preliminary evidence reasonably suspected as criminals.

10. The defendant is a suspect demanded, examined and tried in court.

11. Convict is convicted by a court decision that has obtained permanent legal force.

12. Today is a working day.

Section 4A:

(1) Candidates elected village chief who died, remains incapacitated or resigns for reasons that can be justified before the inauguration, the elected candidate is disqualified and regents / mayors raised

civil servants from the local government district / city as the Acting Chief of the Village.

(2) Acting Village Head as referred to in paragraph

(1) duties and authority of the Village Head up to the inauguration of the Village Head simultaneous live election results in accordance with the provisions of the legislation. 
Article 4B:

(1) Candidates elected village chief named as a suspect and threatened with imprisonment for a minimum of 5 (five) years before the inauguration, the elected candidate remains sworn in as the chief.

(2) Candidates chosen Village Head who identified as suspects in corruption, terrorism, treason and / or criminal offenses against state security before the inauguration, the elected candidate remains sworn in as head of the village and at the first opportunity regents / mayors suspend from office as Chief Village.

(3) Candidates chosen Village Head designated as the accused and threatened with imprisonment for a minimum of 5 (five) years based on the register of a court before the inauguration, the elected candidate remains sworn in as head of the village and on the first occasion the Regent / Mayor suspend from office as Village head.

(4) Candidates for village heads elected defined as a convict and threatened with imprisonment for a minimum of 5 (five) years under a court decision has had permanent legal force before the inauguration, the elected candidate remains sworn in as head of the village and on the first occasion the Regent / Mayor dismiss the concerned from his post as head of the village and raised the Civil Service of the Regional Government of Regency / City as the Acting Chief of the Village.

(5) Elected village head candidate referred to in subsection (1) through (4) were not present at the inauguration considered resigning unless there are justifiable.

(6) Implementation of the provisions of the first opportunity referred to in paragraph (2), (3) and (4) no later than 14 (fourteen) days from the date of appointment.

(7) Acting head of the village as referred to in paragraph

(4) carry out the duties and authority of the village chief

until the inauguration of the village chief village head election results over time through village meetings.

Section 6A:

(1) Civil Servants elected and appointed village chief, concerned exempted temporarily from his post as long as a village chief without losing their rights as civil servants.

(2) Civil Servants elected and appointed village chief as to which referred to in paragraph (1) are entitled to receive rights as a civil servant, an allowance village head and other lawful income derived from the Budget of the Village.

Article 8: 
(1) The village head stops for:
a. die;
b. own request; or
c. dismissed.

(2) The village head is dismissed as referred to in paragraph

(1) c for:

a. end of his tenure;

b. unable to carry out tasks on an ongoing basis or remains incapacitated consecutively for six (6) months due to illness resulting in both physical and mental, are not functioning normally as evidenced by a medical certificate authorities and / or are not known to exist;

c. no longer qualifies as a village head;

d. violates the prohibition as the head of the village;

e. the status change into urban villages, merging two (2) or more villages into 1 (one) new villages, or the elimination of the village;

f. discharge duty as the head of the village; and / or

g. expressed as a convict who was threatened with imprisonment for a minimum of 5 (five) years under a court decision has had permanent legal force.

(3) If the head of the village stopped as referred to in paragraph (1), Village Consultative Body to report to the regent / mayor through the subdistrict head or other designations.

(4) Village Consultative Body leader reports to the regent / mayor referred to in paragraph (3)

case of material load experienced by the head of the village concerned.

(5) Top of the Village Consultative Body leadership report referred to in paragraph (4) regent / mayor conducted a study for the next process. 


\section{CHAPTER IV \\ PHILOSOPHICAL BASIS, juridical, and sociological}

\section{A. Philosophical grounding}

The village is the basis of livelihood of the people in all corners of Indonesia since the first, in which each village has its own autonomy in managing the power system, and governance over the population, local institutions and economic resources. At first the village is a local community organization that has territorial boundaries, populated by a number of residents, and customs have to manage itself. This is called self-governing community. The village designation as a new law community unit known in the Dutch colonial period. The village generally has its own government that managed autonomously without structural hirarkhis- bond with a higher structure.

Philosophically clear that before governance on it there, the village was first there. Therefore, we recommend the village must be the foundation and part of the governance arrangements thereafter. The village has an older governance, should also be at the forefront of every implementation of government affairs and community development. Building village law is the basis of the state administration Indonesia15 This means that the nation is actually located in the village, then the village setting in the Act is very urgent because of the type and the hierarchy of legislation will determine the extent of the setting of the village. This means that the settings in this Act shall also determine the reciprocation of a village that has implications for the existing rule on it.

Democracy is a system that values and governance frame the village. Conceptually, democracy contains

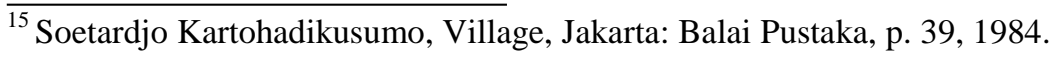


a number of basic principles: representation, transparency, accountability, responsiveness and participation, that all of these principles into the basic foundation for policy management, village planning, financial management and public service village. If these fundamental principles is not in the village, it will display a "single master" autocratic and financial policies and what the village will run on a regular basis, or can be problematic cases that hurts the village. Democracy Village will open space for people to express their aspirations to the village government. Aspiration is the foundation of people's sovereignty has long mandated in the constitution. Democracy is also the arena of mental and personality to educate people so that they are more capable, independent, militants and have no awareness about the management of public goods that affect their lives. Education and learning is important, given the pragmatic society economically and politically conservative, as a result of the times that give priority to the orientation of the material.

Independence and village democracy is a tool and a roadmap to achieve the welfare of the people of the village. Decentralization allows the allocation of resources to the village, and democracy allows the village resource management side with the people of the village. Village rights to manage natural resources, for example, is a very valuable capital for the economy of the people of the village. Similarly, with an allocation of larger villages will be very useful to support the function of the village in the provision of basic services villagers. However, the welfare of rural people more optimal course may not be able to be covered by the village government alone, because it is necessary also government policy that is responsive and participatory, oriented to the improvement of basic services and local economic development. 
As kosekuensi diverse selection then village of institutional arrangements and implementation of village administration also created a variety of choices. However, this Act is necessary to define the standard norms that can be used as a reference dialam village governance. Standards and norms to be followed are as follows:

First, Agar village governance can be more sensitive in understanding the aspirations and problems faced by the community. In this regard there are seven principles in the Village Government emphasized, namely:

a) The principle of Rule of Law

b) Principles of Conduct in the Public Interest

c) principle of Openness

d) principle of Professionalism

e) principle of Accountability

f) The principle of efficiency

g) principle of Effectiveness

Second, Operation conducted by the village administration representatives / consent of the village, the village government and community meetings.

Third, the village representative body or called by any other name is the representative body of the people who run the village of articulation and aggregation functions of the interests of the village; legislative function (regulation); budgeting functions and monitoring functions. Keanggaotaan Village Representative Body can be selected or by consensus gradually in stages in accordance with local customs and traditions. BPD reflect representatives of the elements or groups in rural communities, including the $30 \%$ quota for women. Position, the selection mechanism, requirements, quantity, authority control functions, obligations, rights, ban, meeting mechanism, fixed income and allowances from the next BPD local regulation. In order BPD representative and work effectively, it is designed as a "job" 
a full-time (rather odd). If BPD only as "work" odd, then he just dominated by a group of community leaders and civil servants, which means it does not reflect the representation of many groups in the village. The design of a full-time was also in response and preparation for a number of decentralized planning authority and to the village. Consequently, BPD also earn a salary as well as village officials.

BPD perform the function of the legislature (the regulation of the village), consultative (village development plans), absorb the aspirations of the people, and the control of government institutions to keep Desa.BPD be horizontal accountability. In the context of horizontal accountability, the government of the village or the village chief, responsible to the people with BPD, and communicated accountability to the Regent as a material for the evaluation, supervision and coaching. In addition, it is important also set whether MPs village is voluntary (volunteer) or paid in exchange for a device like a village.

Fourth, the village government led by the village chief or called by another name. The charging process of the village head elections can be done directly or through a chain of citizen deliberation in accordance with local customs and traditions. The village head directly elected for 6-year term and may be reelected. The village head can only be served two consecutive terms. This law states clearly the rights and obligations of the head of the village; This lack of clarity regarding the mechanism of setting the village head elections; duties, powers and obligations of the village chief; requirements to become a village chief; ban for the village chief; dismissal of the Head of the Village; Village Head tenure of 6 years. 
Fifth, the village chief relationship with BPD is based the principle of check balances. The village head or called by other names in the form of a report delivered accountable governance at the Regent; report information on the BPD governance and citizens in the village discussion forum, and openly inform the public.

Sixth Village Consultation is the embodiment of deliberative democracy (deliberative democracy), the model of decision-making by using deliberations to reach consensus collectively, as well as forms of traditional village consultation meetings or deliberations; The village is the highest deliberative forum in making decisions on strategic issues in the village. Strategic issues, among others: Determination of the strategic plan of the village, development planning and issues related to the cooperation with third parties. Village Consultation held at least once a year. Village Council decision is binding for implementation by the village government and village representative body. Village Consultation can be followed directly by all citizens or performed with a model of delegates elected in stages.

Seventh, the village head helped by village government elements which include a village secretary and village. The organizational structure of village government established through regulation by taking into account the model village and village authority. This Act regulates the village (Secretary of the Village and the Village others), both in the recruitment system, allowances, awards. Recruitment of village secretary and village based principles of professionalism, transparency and accountability. If democracy is needed as the political framework of governance of the village, technocracy needed 
as the administrative framework for the village, is primarily concerned with keperangkatan village. But the technocratic framework also consider the local context as the original order. A few key points important in this context.

Eighth, the rural governance process should be open space for substantive democracy. While the dimensions of substantive democracy works in the realm of socio-cultural as well as political and institutional sphere. In the socio-cultural sphere, democracy advocate unity, tolerance, nonviolence, pluralism, inclusiveness, gender equality, and others. In the political sphere and institutional, substantive democracy that must be set explicitly in the legislation is accountability, transparency, responsiveness and participation.

The village government led by the village chief or called by another name. The charging process of the village head elections can be conducted directly or through a chain of citizen deliberation in accordance with local customs and traditions. The village head directly elected for 6-year term and may be reelected. The village head can only be served two consecutive terms. This law states clearly the rights and obligations of the head of the village; This lack of clarity regarding the mechanism of setting the village head elections; duties, powers and obligations of the village chief; requirements to become a village chief; ban for the village chief; dismissal of the Head of the Village; Village Head tenure of 6 years.

Basically, when viewed from the philosophical aspects of village chief was not the leader of the villagers, but rather as an arm of government supra village, which is used to control the population and the land of the village. Village head elected by the people through direct democracy. The village chief electoral provisions directly it is a side of democracy (electoral) at the village level. At the time of the president, governors and regents 
oligarchic determined by parliament, the head of the village actually elected directly by the people. Because of that privilege in the village level is often referred to as a bastion of democracy at grassroots level. But empirical practice of village elections did not fully reflect the will of the people. Pilkades always loaded with engineering and villages supra government control through the requirements formulated in political and administrative.

Socialization conducted by the Ministry of villages, development of lagging regions and transmigration is good enough that one of them is the village head election process has been described in both the socializing through guide books. Based on the Regulation No. 112 of 2014 On the Election of Village Heads are several stages and processes that must be implemented in full by the village government in the selection of village heads.

In the village election implementation sovereignty of the people in the village in order to elect the head of the village that is direct, public, free, confidential, honest, and fair. Not unlike the case also with the direct election of regional heads and the president of the republic of Indonesia. Due to this principle is at the core of the creation of democracy in the village.

There are some important things that should be underlined in this village elections are:

a) The village head elections conducted simultaneously or can be a bumpy one.

b) Village Head Election one on the same day in all the villages in the district / city.

c) Village Head Election conducted in waves at most three times within a period of 6 years with a maximum time interval of 2 years TMT June 2014. 
There is also a section which is divided into four stages in the election of village heads, namely:

a) Preparation;

In the preparation process are important starting from the formation of village election committee at the district / city and village levels and the determination of the voters. The government is expected to help the village administration in the process of an election committee due to a lack of human resources.

b) The candidacy;

In the nomination process is divided into three stages: the registration process with the village head candidate the terms and conditions set forth. The second process is the process of the prospective study, determination and announcement of candidates. This process is done by a selection committee set up by local governments to accommodate the nomination process of the village head. And the last process that the village head candidate campaigns. Things to note are the campaign process, because the process is highly vulnerable to the violation. Explained that the village head candidate may campaign in accordance with the social and cultural conditions of the village. But that may be an argument of if there are violations committed by one of the candidates. Which ensured the campaign process must uphold the principle of honest, open, dialogue and responsible.

c) Voting;

The voting process is done by voting through ballot papers that contain numbers, photos, and the name of the candidate or by the local village community practice. And the process is done by voters punching one candidate on the ballot. And 
the technical process which must be implemented to avoid fraud dilakkan in the voting process.

d) determination;

Determination of the village head candidate are divided into three categories: the village head candidate from the community, the village head candidate of the head of the village or the village, and the village head candidate of the State Civil Apparatus. Determination is done by the election committee reported the results of village elections to the BPD, and BPD submitted a report to the regent / mayor through the subdistrict head, then regent / mayor did ratification and appointment by the decision of the regent / mayor. The whole of the costs borne by the village election district / city APBD and funding from APBDesa to the needs at the polls.

\section{B. The cornerstone of the Juridical}

Juridical grounding can not be released by the Indonesian constitutional foundation that bersendikan above the law. Indonesia is a country that is based on the law (Rechstaat) is not based on power (machtstaat). Therefore every product regulations made law must meet the procedures stipulated by the legislation in compliance with the principles contained in the breath of legal state.

Juridical basis is the consideration or the reasons which illustrate that the rules established to deal with legal issues or fill a legal vacuum by considering the existing rule, which will be modified or be repealed in order to ensure legal certainty and a sense of justice. 
Thus, if implemented, the juridical basis is the legal basis (yuridische gelding), which became the basis of the authority (bevoegdheid or competentie) the making of legislation. Is someone official authority or institution / specific agency had no legal basis specified in the legislation or not.

It is therefore very important legal basis in the loading of legislation which is characterized by:

1. the authority for the maker of laws and regulations, as any legislation should be made by the institutions / bodies or authorities.

2 the suitability of the form or type of legislation with the material being regulated, especially if ordered by the legislation a higher level or equivalent.

3. follow a certain procedure or procedures, if not followed then the legislation is possible null and void or not / do not have binding legal force.

4. not contrary to the laws and regulations of a higher order. An Act should not contain rules that are contrary to the Constitution. Similarly forth until the legislation lower levels.

In addition to determining the basis of the authority of the legal basis is also the basis of the existence or recognition of a particular type of legislation is the juridical basis of the material. Juridical basis points to the substance of the material required to be contained in a specific legislation. Shaping regulations require that certain material things should be arranged in a specific legislation anyway. 
Establishment of the draft Regional Regulation on the nomination, election, appointment, appointment and dismissal of the head of this village aims to give legality to the nomination, election, appointment, appointment and dismissal of the head of the village in the district of .......

Of Legislative nomination, election, appointment, appointment and dismissal of the head of the village will certainly pay attention to laws and regulations as follows:

1. Article 18 Paragraph (6) and Article 33 Paragraph (1) of the Act of 1945

2. Law of the Republic of Indonesia Number 33 of 2004 on Financial Balance Between Central And Local Government

3. Law of the Republic of Indonesia Number 12 Year 2011 concerning the Establishment Regulation Legislation

4. Law of the Republic of Indonesia Number 6 Year 2014 About the village

5. Law of the Republic of Indonesia Number 23 Year 2014 On Local Government

6. Law of the Republic of Indonesia Number 9 Year 2015 on the second amendment to Law No. 23 of 2014 On Local Government

7. Government Regulation in Lieu of Law of the Republic of Indonesia Number 2 Year 2014 on the Amendment of Act No. 23 of 2014 On Local Government

8. Indonesian Government Regulation No. 79 Year 2005 on Guidelines for Development and Supervision of Regional Government

9. Indonesian Government Regulation No. 43 Year 2014 About the Implementing Regulations of Law No. 6 of 2014 About the village

10. Regulation of the Minister of Interior of the Republic of Indonesia Number 1 Year 2014 on the Establishment of the Regional Legal Products

11. Regulation of the Minister of Interior of the Republic of Indonesia Number 111 of 2014 on Guidelines for Technical Regulation In the village

12. Regulation of the Minister of Interior of the Republic of Indonesia Number 112 of 2014 On the Election of Village Head

13. Regulation of the Minister of Interior of the Republic of Indonesia Number 114 of 2014 on Guidelines for Rural Development

14. Regulation of the Minister of Rural, Rural Development, and Transmigration Republic of Indonesia Number 2 Year 2015 About 
Code of Conduct and Decision Making Village Consultation Mechanism

15. Regulation of the Minister of Interior of the Republic of Indonesia Number 80 Year 2015 on the Establishment of the Regional Legal Products

16. Regulation of the Minister of Interior of the Republic of Indonesia Number 82 Year 2015 On Appointment and Dismissal of the Village Head

17. Regulation of the Minister of Interior of the Republic of Indonesia Number 83 Year 2015 On Appointment and Dismissal of the Village

18. Regulation of the Minister of Interior of the Republic of Indonesia Number 84 Year 2015 About the Organizational Structure of the Village Government Work

19. Regulation of the Minister of Interior of the Republic of Indonesia Number 44 Year 2016 About the Village Authority

20. Regulation of the Minister of Interior of the Republic of Indonesia Number 65 Year 2017 on Amendment Minister Regulation No. 112 of 2014 On the Election of Village Head

21. Regulation of the Minister of Interior of the Republic of Indonesia Number 66 Year 2017 on Amendment Minister Regulation No. 82 Year 2015 On Appointment and Dismissal of the Village Head

\section{Runway Sociological}

Providing basic village administration is not solely the government's working in terms of administrative and policies are taken. Due to the sociological aspects of government with communities near, the base penyelenggaraanya based on mutual cooperation.

In the practice of the village administration, the principle of mutual cooperation can be found prominently in the Neighborhood (RT), a regionally based social institutions is the smallest at the village level. RT became a bastion of social security at the lowest level. In the context of sishanrata, RT into a fortress defense for the citizens and villages. Sexy bina security and order as well as the tradition of neighborhood security system owned by RT. In the RT community gathering a lot of bags that are intended to 
supporting the interests of economic resilience (economic survival) residents. RT also collect various types of funding from the community, for the sake of social funds nor for mutual cooperation. But actually formalized RT (institutionalized) as the organization corporatist bottom of the bureaucratic hierarchy Indonesia. RT spearhead bureaucratization and regulations to citizens. According to the formal procedure any matters of administrative services (KTP, SIM, C-1, IMB, SKKB, permit, marriage certificate, birth certificates, land titling, and many more) have to pass through the signature of the RT.

In the operation of the village administration, as already described in the first point will not run smoothly and realize the dream of the villagers with the principle of mutual royongnya if the existence of the village head himself is not accepted by society. The existence of the village head / village should be well received by the community that starts from the village election when following the procedures in accordance with the geography and culture of the people considered not trigger rejection of elected village head.

The village head also required to have roles needed by the villagers, not just positions occupied. Because the essence of which is the personification of the village head and village government representation. All the attention in the village addressed to the Village Head personally, "Black white village is dependent on lurahnya". Kadesh must know all the lives of many people, even if only a leaf falling from a tree. Because the village chief is always sensitive to legitimacy in the eyes of its people. Legitimacy means the recognition of people's power and authority of the village chiefs to act organize and direct people. Chief of a democratically elected village is not necessarily continuous gain legitimacy as a leader in his village. Legitimacy had its origin and 
source. Legitimacy comes to the village head delivered speech, recognized values, and the actions done. Generally, the head of the village believe that the recognition of the people is necessary to build and sustain the existence of the smoothness of the policy and the tasks carried, although each village has its head sizes and different styles in building legitimacy. However, the village head generally build legitimacy in ways that are very personal rather than institutional. The village head easily accepted by residents when a light hand to help and attend events of private citizens, sufficiency and bounteous heart, friendly to its citizens, and others.

The village head always appeared dominant in public affairs and politics, but he did not develop a governance bersendikan transparency, accountability, responsiveness, trust and togetherness. The opposite is true: in a hegemonic subordination to the citizens, because the village head and ditokohkan feel trusted by the citizens. The village head had a self-image as a benevolent or guardian who is believed and entrusted with a mandate by the people, so that village heads need not straightforward to work with the spirit of participatory and transparent, or accountable for these actions and policies in public. On the contrary, the villagers are not too concerned with the performance of the head of the village as village power holders, as far as the Head of the village not to harm the economy and the lives of its citizens directly. Villagers, who have been living in pragmatism and conservatism, was quite satisfied with the appearance of the village head of wily speech in various ceremonial events, populist and friendly greeting citizens, who are willing to sacrifice to spend money from his own pocket to the public interest, promising the construction of physical infrastructure and so on. Society does not seem to have space 
sufficient and capacity for voice and exit of the structural condition of the village elite bias.

The village head that can be accepted by the society must meet the criteria outlined above and in the process of selection of village heads elected all aspects that contribute substantive democracy must realize that the passage of a democratic process.

The role of representative institutions is very important village in the passage of the desired village governance practices. Due to the proximity of the village government and community democratic system that is applied is different from the regional administration. The democratic process is applied that is deliberative in other words that consensus, but by the realization of deliberative democracy (consultative) could not be done by forming the Village Consultative Body which is very limited, but can form other institutions that are larger (eg Consultative Assembly Rural) or a kind of a liquid container such as citizen forums. The most important thing in a deliberative democracy (deliberation) is a process of discussion and debate collectively to seek the common good, which exceeded the electoral process (voting).

With the creation of a democratic atmosphere certainly will not be a conflict in rural communities, if they conflict means that certain elements of deliberative democracy was not met. The absence of an agreement in the deliberation and consensus between citizens through representative institutions.

Examples of conflicts that can occur in the process of village elections if it can not determine the direction of policy in a democratic election of village heads found at the stage of voting if there is the potential that if the analogy can be deduced not creation demoktasi 
substantive in the voting process. "In the case of candidates who obtain the largest number of more than 1 (one), the elected candidate is determined based on the area acquisition wider sound". As was said in the Government Regulation No. 43 of 2014, gave birth to the implementing regulations more concrete in Regulation No. 112 of 2014 on Article 42 (2) and (3) which reads:

a. In terms of the number of candidates elected village chief with the most votes equal more than 1 (one) candidate in the village with TPS is more than 1 (one), the elected candidates determined by a majority vote at the polling station with the highest number of voters.

b. In terms of the number of elected candidates with the most votes equal more than 1 (one) candidate in the village with TPS only 1 (one), the elected candidate is determined based on region of residence with the greatest number of voters.

With practice as designated above article certainly be resistance and an upheaval in rural communities. Practices and conflicts of the article above can be described as follows:

If there are two candidates of the village head who has the same number of votes, it will be set to win the election are candidates for village chief whose voice won at the polling stations with the highest number of DPT. The fundamental question is, what if the sound of the winning candidates in the polling station with the highest number of DPT happen to a place where candidates are domiciled. Emotional closeness with the village community head candidate is not prohibited and be not a problem. However, candidates with the most votes were lost as a result of his voice did not win at the polling stations with the highest DPT, will 
aggrieved about the emotional closeness of the village head candidate is not as good as the candidate who won the election because of his domicile at the polling station. It can be concluded that the practice on the basis of the implications of Article 42 does not reflect a substantive democracy. Things like this is what should be avoided because backwardly trigger conflicts between communities especially when carried out simultaneously.

Then in forming the formulation of local regulations regarding the determination of policy procedures for the election, appointment, appointment and dismissal of the head of this district village

is expected to put the idea to create the conditions that substantive democracy through legal instruments. So the village head election disputes do not occur predicted disputes and conflicts will spread to other regions experiencing conflict if a village in the process of village elections. 


\section{CHAPTER V \\ REACH, DIRECTION SETTING, AND SCOPE OF THE MATERIAL \\ CONTENT OF LAW}

A. Target

Goals in the regulations concerning the nomination, election, appointment, appointment and dismissal of the head of the village is the whole society in living in the district

B. Reach and Direction Setting

Reach setting in an academic manuscript draft regulations regarding the nomination, election, appointment, appointment and dismissal of the head of the village are all activities undertaken everyone in and out of the district

The direction of the setting is the strengthening of the legal framework, improving governance sector supervision in the village, to realize moral attitudes and behavior of people who have integrity and loyalty to the legislation that has been set.

C. Scope Payload Material Act

Rule of law

Definitions nomination, election, appointment, appointment and dismissal of the head of the village:

- $\quad$ The area is the District ......

- Local government was Regents and the Region as an element of local governance processes

- $\quad$ Regent Regent is ......

- The village is a community unit which has the authority to take care of the household based on the right of the origins and customs that recognized in the National Government and is in the District 
- The village government is the implementation of government affairs and public interests in the governance system of the Republic of Indonesia

- The village head is a person in charge of organizing the Village Administration, implement Rural Development, rural community development, and community empowerment as well as responsible for the overall activities of the village administration:

- nomination

- election

- ratification

- appointment

- Inauguration

- discharge

- The campaign is an activity in order to convince the voters by offering a vision, mission and programs of candidates

material Content

a. Implementation

For the implementation of regulatory procedures for the nomination, election, appointment, appointment and dismissal of the head of the government of the District village ...... forming a team coordinator coordination between local government agencies and central government agencies that have relevance to the functions and tasks. Institutional coordination involved in this implementation is Community Empowerment Board and Village Government, and all regional organizations that are in the district administration .......

b. Supervision

District Government ...... provide general oversight to the organizers of regional regulation ordinance 
nomination, election, appointment, appointment and dismissal of the head of the village. Then, as the organizer of supervision submitted to the unit or team formed by the District Government ...... involving elements of village government and community empowerment

C. funding

Overall financing of regional regulation procedures for the nomination, election, appointment, appointment and dismissal of the head of the village were taken from a source of revenue and expenditure budget and other funding sources are legitimate and are not binding.

1. Conditions sanctions

Penalties are given to the public in this case individual or group that intentionally or planned for violation of the provisions that have been set then given administrative sanctions and social as well as shape.

Penalties are given to every individual can be a coaching and so on up to the administrative sanctions provided by the District Government ......

2. Implementation

Regional regulatory procedures for the nomination, election, appointment, appointment and dismissal of the head of a whole village implemented by individuals, communities, groups and village governments are domiciled in the territorial district ......, with material covering the implementation of the nomination, election, appointment, induction and the dismissal of the head of the village

3. Supervision

District Government ...... provide general guidance to the village administration. 
Local government set up a coordination team which is a combination of activities relevant stakeholders nomination, election, appointment, appointment and dismissal of the head of the village with the aim to become the overall coordination and supervision of the implementation of the Regional Regulation nomination procedures, selection, recruitment, appointment and dismissal of the head of the village.

4. Evaluation

To measure and determine the success of procedures for the nomination, election, appointment, appointment and dismissal of the head of the village is an evaluation by the agency that is determined by the local government in this case the agency will be governed by the regulations and a decree.

5. Financing

The cost of implementing regional regulation ordinances nomination, election, appointment, appointment and dismissal of the village head charged to the Budget of the District or other sources that

valid and binding

6. Closing

Things that have not been regulated in this area in respect of the technical implementation will be further regulated by decree 


\section{CHAPTER VI}

\section{CLOSING}

\section{A. Conclusion}

Based on the description that has been discussed in previous chapters, it will be able to put forward some conclusions as follows:

1. The fundamental problem in the District of ...... relating to village elections is the absence of regional regulation which comprehensively regulates this matter in accordance with the provisions of Law No. 6 of 2014 on the village, Government Regulation No. 43 Year 2014 concerning the Implementation Regulations Act of No. 6 of 2014 on the village, and the Minister Regulation No. 112 on the Election of the chief. The Third legislation mandates on village elections simultaneously. Empirical issues related to village elections in the District of is a weak understanding of the community and the village head candidate against legislation on procedures for the nomination, election, appointment, appointment and dismissal of the head of the village. Another problem relates to the independence of the election committee, conflicts of interest, and the intervention of local governments in the process of village elections. Distribution ...... district includes 82 villages with 10 districts and also raises its own problems, especially with regard to the implementation of village elections. This problem is also related to the remaining term of the head of the village different, so it should be structured periodization of his election.

2. Provincial Regulation on the new village head elections in lieu of District Regulation No.

31 of 2007 on Procedure of Nominations, Election, Appointment, Inauguration, Termination Village Chief Dan 
the Village needed to answer the demands of the legislation of the village.

3. The philosophical foundation of local regulations on village elections departs from the original democracy that is owned by the village. Recognition of the village administration is recognition, so it should be recognized as the original rule. Sociological grounding in the District of ...... relating to Village Head Election is the readiness of society to the democratization process of village elections. While the legal basis relating to the legal basis for the establishment of local regulations, especially with the enactment of Law No. 6 of 2014 About the village.

4. Target and reach intending direction is achieved by a local regulation on village head elections are adapted to the direction of the setting in the Minister of Home Affairs Number 112 of 2014 on the Election of Village Head, which mandates the selection of village heads in unison. Directions setting to be achieved in the draft regulations on village election is about village elections simultaneously and replacement time between village heads who have outgoing current village elections simultaneously carried out. In general, the direction of the setting bylaw will include arrangements regarding Discharge and Filling Vacancies The position of Head of the village, periodicity of elections, Elections, Head of the village, Village authorities and civil servants who become candidates for village chief, election and inauguration, monitoring and dispute resolution, financing, and sanctions , 


\section{B. Recommendation}

Academic papers on the Election of Local Regulation village head is a study that village elections could take place simultaneously and based on the rule of law. To that end, the District Government ...... should further examine and prepare local regulations in the form of regulations and decisions regents regents to support the technical applicability of these regulations. 
ANNEX CONCEPT PRELIMINARY BILL

Act Early concept consisting of the proposed provisions on the basis of academic description.

preamble:

- that pursuant to Act No. 6 of 2014 About the village and Government Regulation No. 47 of 2015 on the Amendment of Government Regulation No. 43 Year 2014 concerning the Implementation Regulations of Law No. 6 of 2014 About the village needs to be created District Regulation ..... . on Procedures for Nominations, Selection, Appointment, Inauguration, Termination Head of Village in the District;

- that Regulation

on Procedures Nominations, Selection, Appointment, Inauguration, Termination Head of Village and the Village is no longer in accordance with the legislation in force, it is necessary to establish Procedure candidacy, the Election, Appointment, Inauguration, and Dismissal Village Chief;

- that the considerations referred to in paragraphs $a$ and $b$ need to establish Regional Regulation on Procedures Nominations, Selection, Appointment and Dismissal of Chief Inaugural Village in the District;

Legal basis:

- Article 18, paragraph 6 of the Constitution of the Republic of Indonesia Year 1945;

as amended by Act

No. 6 of 2000 on 
changes to Law No. 46 of 1999 on the Establishment of North District ......................................... and

Regency of West Southeast ......... (State Gazette Year 2000

Number 23, Additional State Gazette No. 3961);

Law No. 33 of 2004 on Financial Balance between Central and Regional Government (State Gazette of the Republic of Indonesia Year 2004 Number 126, Supplement to the State Gazette of the Republic of Indonesia Number 4438);

Law Number 12 Year 2011 on the Establishment of Legislation (State Gazette of the Republic of Indonesia Year 2011 Number 82, Supplement to the State Gazette of the Republic of Indonesia Number 5234);

Act No. 6 of 2014 on Village (State Gazette of the Republic of Indonesia Year 2014 Number 7, Supplement to the State Gazette of the Republic of Indonesia Number 5495);

- Law Number 23 Year 2014 regarding Regional Government (State Gazette of the Republic of Indonesia Year 2014 Number 244, Supplement to the State Gazette of the Republic of Indonesia Number 5587)) as already amended several times the latest by Law No. 9 of 2015 concerning the Second Amendment Act Law Number 23 Year 2014 regarding Regional Government (State Gazette of the Republic of Indonesia Year 2015 Number 58, Supplement to the State Gazette of the Republic of Indonesia Year 2015);

- Government Regulation No. 79 Year 2005 on Guidelines for Development and Control of Local Government (State Gazette of the Republic of Indonesia Year 2005 Number 165, Supplement to the State Gazette of the Republic of Indonesia Number 4593);

- Government Regulation No. 43 Year 2014 concerning the Implementation Regulations of Law No. 6 of 2014 on Village (State Gazette of the Republic of Indonesia Year 2014 Number 123, Supplement to the State Gazette of the Republic of Indonesia Number 5539) 
As amended by Government Regulation No. 47 Year 2015 on the Amendment of Government Regulation No.

432014 About the Implementing Regulations of Law No. 6 of 2014 on Village (State Gazette of the Republic of Indonesia Year 2015 Number 157, Supplement to the State Gazette of the Republic of Indonesia Number 5717);

- Minister Regulation No. 112 of 2014 On the Election of Village Heads (Official Gazette of the Republic of Indonesia Year 2014 No. 2092);

- Minister Regulation No. 80 Year 2015 on the Establishment of the Regional Legal Products (Official Gazette of the Republic of Indonesia Year 2015 No. 2036

- Minister Regulation No. 82 Year 2015 On Appointment and Dismissal of the Village Head (Official Gazette of the Republic of Indonesia Year 2016 Number 4);

- Minister Regulation No. 83 Year 2015 on Appointment and Dismissal of the Village (Official Gazette of the Republic of Indonesia Year 2016 No. 5);

- Minister Regulation No. 84 Year 2015 About the Organizational Structure and Work Procedures Village Government (Official Gazette of the Republic of Indonesia Year 2016 No. 6);

- Minister Regulation No. 44 Year 2016 on the Authority of the Village (Official Gazette of the Republic of Indonesia Year 2016 No. 1037);

- Regulation of the Minister of Interior of the Republic of Indonesia Number 65 Year 2017 on Amendment Minister Regulation No. 112 of 2014 On the Election of Village Heads (Official Gazette of the Republic of Indonesia Year 2017 No. 1221) 
General requirements :

- The area is the District .......

- Regent Regent is .......

- Local Government is the Regent as a component of the Local Government which led the implementation of government affairs under the authority of the autonomous region.

- Regional Representatives Council, hereinafter referred to Parliament is DPRD

- Camat is subdistrict in the district of .......

- Supervisory Committee is supervising committee nomination and implementation of village elections in the District ............ that domiciled subdistrict level.

- The village is a unit of community has boundaries that are authorized to regulate and manage the affairs of government, the interests of the local community by community initiatives, the right of origin, and / or customary rights recognized and respected in the governance system of the Republic of Indonesia.

- The village government is the Head of Village and the Village as part of administrators of the village.

- Village Consultative Body, hereinafter referred to BPD are institutions that carry out functions of government whose members are representatives of the inhabitants of the village based representation of the region and determined democratically.

- Village Consultation is organized by the BPD deliberations on the selection of interim village chief.

- Village elections is the implementation of the sovereignty of the people in the village in order to elect the head of the village that is direct, public, free, confidential, honest, and fair.

- The village head is the village government officials who have the authority, duties and obligations to carry out household duties of his village and the Government and 
Local government;

- Village head of the election committee village level, hereinafter referred to the Election Committee is the committee formed by the BPD to organize the village head elections;

- Village head of the election committee hereinafter referred to as the district level District Electoral Committee is the committee that established the Regent at the district level in support of the village chief elections.

- Candidate Village Head is the village chief candidates established by the selection committee as a candidate has the right to be elected as head of the village;

- Elected Village Head candidate is a candidate for village chief who gained the most votes in the election of the chief.

- Acting Head of the village is an official appointed by the competent authority to carry out the duties, rights and authority as well as the obligations of the village chief in a specified period;

- Village head of the election committee in the village is a committee formed to carry out the selection of BPD village chief.

- Voters are concerned villagers and have met the requirements for voting in the election of village chief;

- While the Voters List, hereinafter referred to DPS is the voters list is based on data the voters list the last General Election has been updated and checked back in on the truth and coupled with new voters;

- Additional Voters List is a list of voters which is based on the proposal of the voters, because he has not been registered in the Register of Electors meantime;

- Voters list hereinafter called DPT is a list of voters who have been assigned by the Election Committee as 
basis for determining the identity of the voter and the number of voters in the election of village chief;

- The campaign is an activity undertaken by the Village Head candidate to convince voters in order to get support.

- Polling Place, hereinafter referred to as TPS, is the implementation of the polling place.

- Today is a working day.

materials:

Purpose, Objectives and Targets

The purpose of the Regulation to provide legal certainty associated procedures for the nomination, election, appointment, appointment and dismissal of the Head of the Village

The goal specifically is to provide an overview and guidance to stakeholders on procedures for the nomination, election, appointment, appointment and dismissal of the Head of the village.

General purpose is to provide knowledge to the entire community related ...... District on nomination procedures, selection, recruitment, appointment and dismissal of the Head of the Village

Goals in the regulations concerning the nomination, election, appointment, appointment and dismissal of the head of the village is the whole society in living in the district 
appraisal

To measure and determine the success of procedures for the nomination, election, appointment, appointment and dismissal of the head of the village is held by the ratings agencies determined by the local government in this case the agency will be governed by the rules and decrees Regent.

implementer

Regional regulatory procedures for the nomination, election, appointment, appointment and dismissal of the head of the village is generally carried out by the whole individual, community, and government groups who live in the village ...... territorial district, with material covering the implementation of the nomination, election, appointment, appointment and dismissal of the head of the village. Technically implemented by some elements of them,

1. Election Committee in charge of the district level

- plan, coordinate and execute all phases of the electoral district level;

- conduct technical guidance implementing village elections to the village election committee village level;

- set the number of ballots and ballot boxes;

- facilitate printing of ballot papers and ballot boxes as well as the manufacture of other election paraphernalia;

- deliver ballots and ballot boxes and other election paraphernalia to the election committee;

- facilitate the settlement of problems of village election district level;

- to supervise the implementation of village elections and to report and make recommendations to the regents; and

- evaluating and reporting on the implementation of elections. 
2. Village Head Election Committee in charge

- plan, coordinate, organize, supervise and control all phases of the election;

- plan and submit charges to the Regent through the subdistrict head election;

- conduct voter registration and establishment;

- hold the netting and screening candidates;

- determine the candidates who meet the requirements;

- establishing procedures for the implementation of the elections;

- establishing procedures for the implementation of the campaign;

3. Village Consultative Body tasked to prepare everything related to election of village chief, among others:

- notification village consultative body to the village head on the end of the term of office that delivered 6 (six) months before the end of office;

- an election committee head of the village by village consultative body set within a period of ten (10) days after notice of the end of the term of office;

4. Supervisory committee election, set by decree sub-district, which has the task of:

- oversee all phases of the conduct of elections Village Chief;

- receive reports of violations of the stages of village elections; and resolve disputes arising in the conduct of elections Village Head 
Financing

Overall financing of regional regulation procedures for the nomination, election, appointment, appointment and dismissal of the head of the village were taken from a source of revenue and expenditure budget and other funding sources are legitimate and are not binding.

\section{Sanctions}

Penalties are given to the public in this case the individual who tried to violate these regulations will be sanctioned form of guidance by the village officials to the security forces when lead to disturbance of order.

Penalties given to pelakasana as stipulated in the Regulation are given a warning and so on until the administrative sanctions

Criminal sanctions will be imposed against those who have committed criminal acts related to the activities Selection, appointment, appointment and dismissal of the Head of the Village in accordance with the legislation in force. 
Reference:

A. Hasan Afandi and M. Chairul Basrun Umanailo, 2018. "Watudakon Citizens 'Social Conflict on Joker Toll Road Development in 2017 in Kesamben District, Jombang Regency," J. Soc. Sci. Res., no. 5, pp. 656-661.

Abdurokhman, Drs., M.Pd. 2014. Pengembangan Potensi Desa. Widyaiswara pada Kantor Diklat Kabupaten Banyumas

Arie Sujito, 2013. Konteks dan Arah Pembaruan Desa Dalam Advokasi Rancangan Undang-Undang Desa. Yogyakarta. Jurnal Mandatory IRE

B. S. Amanto, M. C. B. Umanailo, R. S. Wulandari, T. Taufik, and S. Susiati, 2019. "Local Consumption Diversification,” Int. J. Sci. Technol. Res., vol. 8 , no. 8.

B. Sam et al., 2019. "Female Feminism in the Customary Island of Buru," Int. J. Sci. Technol. Res., vol. 8, no. 8.

Buechler, Steven M. 1993. Beyond Resource Mobilization?Emerging Trends in Social Movement Theory.The Sociological Quarterly, Vol. 34, No. 2.

Dwipayana, Ari dan Sutoro Eko dkk. 2003. Membangun Good Governance di Desa. Yogyakarta. IRE Press. Hikmat, R. Harry. 2001. Strategi Pemberdayaan Masyarakat. Bandung. Humaniora Utama Press.

Indonesian Government Regulation No. 43 Year 2014 About the Implementing Regulations of Law No. 6 of 2014 About the village

Kanter, Rosabeth Moss. (1968). Commitment and Social Organization:A Study of Commitment Mechanisms in Utopian Communities. American Sociological Review, Vol. 33, No. 4.

Klandermans, Bert \& Conny Ronggeband. 2010. Handbook f Social MovementsAccros Disciplines. Amsterdam. Springer.

Klandermans, Bert, Jose Manuel Sabucedo, Mauro Rodriguez, dan Marga de Weerd. (2002). Identity Processes in Collective Action Participation: Farmers`Identity and Farmers` Protest in the Netherlands and Spain. Political Psychology, Vol. 23, No. 2.

Klandermans, Bert. 1984. Mobilization and Participation: Social-Psychological Expansions of Resource Mobilization Theory. American Sociological Review, Vol.49, No. 5

L. Rumkel, B. Sam, and M. C. B. Umanailo, 2019. "Village Head Partnership, Village Consultative Body and Customary Institution in Village Development,” Int. J. Sci. Technol. Res., vol. 8, no. 8

Latar, Sahid Ridwan. 2015. Kalesang Desa, Studi kasus tentang Implementasi Program Kalesang Desa di Kabupaten Buru. Jurusan Ilmu Pemerintahan Fakultas Ilmu Sosial Dan Ilmu Politik Universitas Muhammadiyah Malang.

Lindawati, Lisa . 2013. Komunikasi Pembangunan dan Kemandirian Desa. Tesis. Locher, David A. 2002. Collective Behavior. New Jersey: Prentice Hall

Locher, David A. 2002.Collective Behavior. New Jersey: Prentice Hall.

M. C. B. Umanailo, 2019. "Consumption Diversification of Local Community," J. AGRISEP Kaji. Masal. Sos. Ekon. Pertan. dan Agribisnis, vol. 18, no. 1, pp. 61-74, Mar.

M. C. B. Umanailo, M. Yulisvestra, K. K. Oki, W. Mulyasari, and R. Ridwan, 2019. "The Thought of Emile Durkheim in the Contestation of Development in Indonesia,” Int. J. Sci. Technol. Res., vol. 8, no. 8.

M. C. B. Umanailo, N. Handayani, A. Masniati, S. H. Makatita, and S. Lisaholit, 
2019. "The Urbanization and Diversification of Farmland Namlea Village," Int. J. Sci. Technol. Res., vol. 8, no. 8.

M. Chairul Basrun Umanailo, 2019. "Discourse on the Consumerist Community Consumption,” J. Soc. Sci. Res., no. 54, pp. 1181-1186, Apr.

Marx, Gary T. and James L. Wood. 1975. "Strands of Theory and Research in Collective Behavior." Annual Review of Sociology 1.

Muhi, Dr. Ir. Ali Hanapiah MP. 2011. Institut Pemerintahan Dalam Negeri, Jatinangor, Jawa Barat. Mustika, Zed. 2004. Metode Penelitian Kepustakaan. Jakarta. Yayasan Obor Nasional.

Pichardo, Nelson A. 1988. Resource Mobilization: An Analysis of ConflictingTheoretical Variations. The Sociological Quarterly, Vol. 29, No. 1 .

Prasojo, Dr. Eko. 2003. Perspektif Membangun Partisipasi Publik. PKSPSP. FISIP Universitas Indonesia

R. Umanailo, M. Nawawi, M. C. B. Umanailo, S. Malik, and I. Hentihu, 2019. "Conversion of Farmland Namlea Subdistrict," Int. J. Sci. Technol. Res., vol. 8 , no. 8 .

Regulation of the Minister of Interior of the Republic of Indonesia Number 111 of 2014 on Guidelines for Technical Regulation In the village

Regulation of the Minister of Interior of the Republic of Indonesia Number 112 of 2014 On the Election of Village Head

Regulation of the Minister of Interior of the Republic of Indonesia Number 65 Year 2017 on Amendment Minister Regulation No. 112 of 2014 On the Election of Village Head

Regulation of the Minister of Interior of the Republic of Indonesia Number 66 Year 2017 on Amendment Minister Regulation No. 82 Year 2015 On Appointment and Dismissal of the Village Head

Regulation of the Minister of Interior of the Republic of Indonesia Number 82 Year 2015 On Appointment and Dismissal of the Village Head

S. Rachman, H. Hamiru, M. C. B. Umanailo, Y. Yulismayanti, and H. Harziko, 2019. "Semiotic Analysis of Indigenous Fashion in The Island of Buru," Int. J. Sci. Technol. Res., vol. 8, no. 8. 